\title{
Ku reformie średniowiecznych mendykantów. Macieja Hayna ( $† 1477)$ \\ Exhortatio ad meditationem et conformationem passionis Christi
}

Dominikański konwent św. Wojciecha we Wrocławiu, z którym związany był Maciej Hayn - autor Exhortatio ad meditationem et conformationem passionis Chri$s t i, \mathrm{w}$ XV wieku po krakowskim klasztorze Św. Trójcy stanowił drugi najważniejszy ośrodek życia intelektualnego dominikanów prowincji polskiej. Był on siedzibą nie tylko szkoły konwentualnej, w której odpowiednio wykształcony zakonnik, pełniący funkcję lektora, prowadził wykłady z teologii przeznaczone dla wszystkich mieszkańców danego klasztoru, lecz także szkoły partykularnej (międzyklasztornej), w której odbywały się studia o szerszym programie. We Wrocławiu

${ }^{1}$ Problematyka kultury intelektualnej dominikanów wrocławskich była już wielokrotnie poruszana. Do najważniejszych opracowań poruszających to zagadnienie należą następujące publikacje: G. M. Löhr, Breslauer Dominikaner des 15. Jahrhunderts auf auswärtigen Hochschulen. „Archivum Fratrum Praedicatorum” T. 13: 1943, s. 162-178; P. Kielar, Studia nad kultura szkolna i intelektualną dominikanów prowincji polskiej w średniowieczu. W: Studia nad historia dominikanów w Polsce 1222-1972. T. 1. Pod red. J. Kłoczowskiego. Warszawa 1975, s. 456-515; J. Kłoczowski, Dominikanie polscy na Śląsku w XIII-XIV wieku. Lublin 1956, s. 214-234; J. B. Korolec, Wstęp do badań nad życiem umysłowym dominikanów wrocławskich $w$ średniowieczu. „Materiały i Studia Zakładu Historii i Filozofii Starożytnej i Średniowiecznej” T. 8: 1974, s. 126-159; M. Bukała, Zagadnienia ekonomiczne $w$ nauczaniu wrocławskiej szkoły dominikańskiej w późnym średniowieczu. Wrocław 2004, passim; tenże, Dominikanie wrocławscy jako studenci i wykładowcy Studiów Generalnych prowincji angielskiej w pierwszej połowie XV wieku. „Śląski Kwartalnik Historyczny Sobótka” T. 55: 2000, nr 4, s. 557-564; S. Zonenberg, Śląacy z polskiej prowincji dominikańskiej na studiach $w$ Wiedniu $w$ XV i na początku XVI wieku. „Studia Źródłoznawcze” T. 43: 2005, s. 111-124; K. Kaczmarek, Szkoły i studia polskich dominikanów w okresie średniowiecza. Poznań 2005, passim; tenże, Konwent dominikanów wrocławskich w późnym średniowieczu. Poznań-Wrocław 2008, s. 131-165. 
obejmowały one aż trzy dziedziny, mianowicie oprócz teologii także „sztuki” oraz filozofię. Dzięki temu wielu zakonników mogło zyskać stosowne przygotowanie do studiów wyższych, również poza macierzystą prowincją ${ }^{2}$.

Dotychczas poznane źródła nic nie mówią o dacie urodzenia ani młodości Macieja Hayna, nie wiemy, w którym roku wstąpił do zakonu dominikańskiego, ani czy miało to miejsce we Wrocławiü3 ${ }^{3}$ Na pewno wyróżniał się w trakcie pierwszych lat nauki, gdyż władze zakonne naukę za granicą umożliwiały tylko najzdolniejszym braciom. W latach 1443-1445 przebywał on w Kolonii, gdzie wraz z innym dominikaninem z prowincji polskiej - Pawłem Meysnerem uczęszczał do studium generale. Tam prawdopodobnie obydwaj bracia zetknęli się z prądem filozoficznym via antiqua, gdyż Kolonia była wówczas najważniejszym ośrodkiem chrześcijańskiego arystotelizmu. Następnie udał się do konwentu wrocławskiego, aby pełnić tam funkcję kursora teologii, czyli początkującego lektora, którego zadaniem było czytanie i objaśnianie Biblii oraz Sentencji Piotra Lombarda. Po roku został wysłany na dalsze studia zagraniczne do Wiednia (1448-1449), następnie do Paryża (1449-1450). Podczas pobytu w tamtejszym konwencie św. Jakuba sporządził liczne wyciągi z pism św. Tomasza z Akwinu. Do prowincji macierzystej powrócił jako bakałarz teologii w roku 1450, o czym świadczy wiele dokumentów oraz zapis w katalogu braci sporządzonym przez Jana Advocati OP. Zapewne gdyby takiego stopnia nie uzyskał, nie mógłby objąć stanowiska „bakałarza sentencjariusza” w krakowskim Studium Generale.

${ }^{2}$ Zob. K. Kaczmarek, Konwent dominikanów..., s. 137-165.

${ }^{3}$ Nt. biografii Macieja Hayna zob. Archiwum Polskiej Prowincji Dominikanów w Krakowie, sygn. Ao 44: P. Kielar, Wykazy studentów i profesorów prowincji polskiej dominikanów w średniowieczu, (69-70); G. M. Löhr, Breslauer Dominicaner des 15 Jahrhunderts auf auswärtigen Hochschulen. „Archivum Fratrum Praedicatorum” T. 13: 1943, s. 171; W. Seńko, Maciej Hayn OP. „Materiały i Studia Zakładu Historii i Filozofii Starożytnej i Średniowiecznej” T. 3: 1964, s. 38-43; J. B. Korolec, Maciej Hayn. W: Polski Słownik Biograficzny. T. 19. Kraków 1974, s. 12-13; tenże, Studia nad szkolnictwem dominikańskim, Maciej Hayn. W: Studia nad historia dominikanów w Polsce. 1722-1972. T. 1. Warszawa 1975, s. 517-542; T. Kaeppeli, Scriptores Ordinis Praedicatorum Medii Aevi. T. 3. Roma 1980, s. 129-130; S. Dobrzanowski, Hayn Maciej. W: Słownik polskich teologów katolickich. T. 1. Warszawa 1981, s. 29-31; M. Markowski, Dzieje Wydziału Teologii Uniwersytetu Krakowskiego w latach 1397-1525. Kraków 1996, 175-246; W. Bucichowski, Lista lektorów dominikańskich prowincji polskiej od erygowania prowincji (1225) do roku 1525. „Przegląd Tomistyczny” T. 6/7: 1997, s. 159, 161; M. Bukała, Dominikanie wrocławscy jako studenci i wykładowcy studiów generalnych prowincji angielskiej w pierwszej połowie XV wieku. „Śląski Kwartalnik Historyczny Sobótka” T. 55: 2000, s. 562-563; K. Kaczmarek, Szkoły i studia..., s. 505-506; T. Gałuszka, Hayn Maciej. W: Encyklopedia Filozofii Polskiej. T. 1. Lublin 2011, s. 478-479. 
W roku 1450 generał zakonu dominikanów Bartłomiej Texier mianował go swoim wikariuszem we Wrocławiu, a za zadanie wyznaczył mu wdrażanie reformy obserwanckiej we wrocławskich konwentach św. Wojciecha i św. Katarzyny. Chociaż funkcję tę Hayn sprawował aż do śmierci 13 stycznia 1477 roku, zdołał zapisać się na Uniwersytet Jagielloński w 1454 roku i prowadzić wykłady ad magisterium na wydziale teologicznym tegoż uniwersytetu w roku akademickim 1456/57. Wśród piętnastowiecznych pisarzy i naukowców dominikańskich, należących do prowincji polskiej, Maciej Hayn zajmuje ważną pozycję zarówno ze względu na długość odbytych studiów zagranicznych, jak i liczbę pozostawionych dzieł. W dawnych zbiorach biblioteki dominikanów wrocławskich (obecnie należących do Biblioteki Uniwersyteckiej we Wrocławiu) oprócz Exhortatio ad meditationem et conformationem passionis Christi odnajdujemy kilkanaście traktatów, kazań i ekscerptów, które przypisuje się Haynowi ${ }^{4}$, jednak dotychczas wydano jedynie wyimki z De bonitate et malitia actuum humanorum ${ }^{5}$.

Exhortatio oznacza po łacinie „zachęta”, „wezwanie”, a więc celem autora było zachęcenie odbiorców do wykonania jakichś czynności. Pisma o podobnej formie odnajdujemy zarówno u starożotnych ojców Kościoła, np. Ambrożego (Exhortatio uirginitatis), jak i u pisarzy średniowiecznych, np. Anzelma z Canterbury (Exhortatio ad contemptum temporalium et desiderium aeternorum). Znaczenie rzeczownika meditatio w tytule nie nasuwa wątpliwości - rozważanie, rozmyślanie. Jeśli zaś chodzi o conformatio, wyjaśnienie znajduje się w tekście: „Naśladowanie zaś lub podążanie za wzorem Męki, o której on sam mówi: «każdy kto chce iść za mną, niech się sam siebie zaprze, i weźmie krzyż swój, a naśladuje mnie», jak również Piotr Apostoł: «Chrystus za nas cierpiał, zostawiając wam przykład, abyście wstępowali w jego ślady»” (Mt 16, 24). Dlatego tytuł dzieła można przetłumaczyć: „Zachęta do rozważania i naśladowania Męki Chrystusa”.

Maciej Hayn swoją „zachętę” skierował do konkretnych osób, a mianowicie do swoich dominikańskich współbraci, do których wielokrotnie zwraca się, używając sformułowania fratres karissimi (bracia najdrożsi), oprócz tego często stosuje określenie frater quilibet (jakiś brat). Całe dzieło można podzielić na dwie części: wstępną (I Q 42, f. 127r - 128r; I Q 104, f. 59r - 59v) i właściwą (I Q 42, f. 128v - 141r; I Q 104 f. 59v - 68v). Pierwsza zawiera wprowadzenie oraz uzasadnia konieczność rozważania i naśladowania Męki Pańskiej. Zaczyna się ona

${ }^{4}$ Wykaz owych dzieł można znaleźć w: W. Seńko, Maciej Hayn..., s. 38-43; M. Bukała, Zagadnienia ekonomiczne..., s. 192-193.

${ }^{5}$ Zob. J. Korolec, Studia nad szkolnictwem..., s. 517-542. 
cytatem biblijnym z Księgi Joela (Jl 2, 12-13), który należy do czytania ze Starego Testamentu przeznaczonego na Środę Popielcową: „Conuertimini ad me in toto corde uestro in ieiunio et fletu et planctu et scindite corda uestra” - „Nawróćcie się do mnie ze wszystkiego serca waszego w poście i w płaczu i rozdzierajcie serca wasze". Według Hayna cytat przedstawia sposoby najlepszego nawrócenia, mianowicie całym sercem oraz za pomocą postu, płaczu i lamentu, a także skruchy. Hayn omawia każdą z metod, a następnie stwierdza, że postulaty zawarte w Księdze Joela najlepiej wypełniał sam Chrystus, człowiekowi natomiast pozostaje częste wspominanie Męki Pańskiej. Cały powyższy wywód, poparty odwołaniami do Biblii oraz św. Augustyna, ma za zadanie wyjaśnić, dlaczego wydarzenia poprzedzające śmierć Jezusa na krzyżu, zapisane na kartach Ewangelii, są szczególnie istotne w czasie Wielkiego Postu.

W dalszej części wstępu autor stara się uzasadnić konieczność częstego czytania opisu cierpień Chrystusa ze względu na korzyści, jakie można dzięki temu uzyskać. Pilna lektura pasji oświeca umysł, rozważanie sprawia, że uczucia rozpalają się od miłości Jezusa, a czynienie się podobnym do niej pomaga dążyć do doskonałości i właśnie to działanie jest najbardziej wartościowe. Osoba, która bierze na siebie krzyż Zbawiciela, zostaje obdarzona wieloma łaskami: miłością samego Zbawiciela, oddaleniem smutku, zmniejszeniem kar czyśćcowych, odpuszczeniem grzechów.

Następnie, kiedy już wiadomo, jak ważna i pożyteczna jest Męka Chrystusa, opisany zostaje sposób jej przedstawienia w drugiej części dzieła. Ponieważ słaby umysł ludzki nie może przyswoić zbyt wiele naraz, autor postanawia podzielić tekst na tyle kawałków (w oryginale użyto słowa: morsellus - kęs, kawałek pożywienia), ile dni ma Wielki Post, bracia natomiast mają je przyjmować tak, jak w czasach św. Dominika. Zatem w zamyśle Hayna tekstu nie należało czytać w całości za jednym razem, lecz w kolejne dni, tak aby umożliwić czytelnikom lub słuchaczom rozważanie każdej z części osobno.

Druga część dzieła składa się z czterdziestu trzech morselli, a każdy z nich $\mathrm{z}$ passio i conformatio. Zgodnie $\mathrm{z}$ tym, co autor zapowiada we wstępie, powinno ich być tylko czterdzieści, czyli tyle, ile jest dni Wielkiego Postu, jednak być może Maciej nie uwzględniając Triduum Paschalnego, przeznaczył morselli na wszystkie niedziele Wielkiego Postu i tak otrzymał liczbę czterdzieści trzy. Passiones składają się na opis Męki Pańskiej. Niektóre z nich zawierają tylko jedno zdanie, inne są dłuższe, ale wszystkie mają podobną budowę. Najczęściej zaczynają się od zdania podrzędnie złożonego ze spójnikiem postquam albo zdania złożonego współrzędnie, w którym podmiotem pierwszego zdania jest Jezus. Conformationes natomiast zawierają wskazówki i zalecenia dotyczące życia zakonnego. Także 
one zbudowane są według stałego schematu - zaczynają się od słowa sic (tak), które pełni funkcję łącznika między passio a conformatio i ma za zadanie pokazać, że dana conformatio ściśle odnosi się do poprzedzającej ją passio.

Passiones zawarte w Exhortatio są oparte głównie na przekazie ewangelicznym. Nie odwzorowują one jednak dokładnie opisu biblijnego, gdyż autor skupia się tylko na niektórych sytuacjach z życia Chrystusa. Nie przytacza między innymi sceny odcięcia ucha żołnierzowi przez jednego z uczniów, pomocy Szymona z Cyreny, ani kobiet, które płakały nad Jezusem prowadzonym na śmierć. Nie ma tam też mowy o zdradzie Judasza. Mimo tych braków parafraza jest spójna i nie zawiera sprzeczności.

Przy układaniu Conformationes Hayn szuka sytuacji, w których może znaleźć się zakonnik, i porównując je do wydarzeń z życia Jezusa, daje konkretne wskazówki dotyczące właściwego postępowania, tak żeby spełnione zostało założenie obrane na początku Exhortatio, czyli: upodabnianie się do Chrystusa cierpiącego. Swoje wnioski Hayn popiera cytatami z Biblii i licznych autorów chrześcijańskich, jednak całość zdaje się być bardziej tekstem autorskim niż kompilacją. Najbardziej podkreśla pokorę, z jaką Chrystus znosił wszelkie trudności oraz posłuszeństwo wobec woli Ojca i pragnie, aby jego współbracia szczególną uwagę zwrócili na te aspekty życia zakonnego.

Jeśli chodzi o autorytety pozabiblijne, Hayn najczęściej odwołuje się do bł. Henryka Suzo (1295-1366), dominikanina zaliczanego do grona tzw. mistyków nadreńskich, zwanego też Frater Amandus. Był on autorem dzieła pt. Horologium sapientiae (Zegar mądrości) - dialogu między personifikacją Mądrości Bożej (sapientia) i jej uczniem (discipulus). Sapientia ma symbolizować kogoś, kto żyje w wierze i umiłowaniu Chrystusa, discipulus zaś grzesznika, który pragnie przebłagać Jezusa za swoje występki. Poprzez ich dialogi Suzo ukazuje, na czym polega prawdziwa mądrość i stara się zachęcić czytelnika do większej pobożności, zalecając także częste rozważanie Męki Pańskiej. Być może zatem to właśnie lektura Horologium sapientiae skłoniła Hayna napisania Exhortatio.

\section{Edycja tekstu i przekład na język polski}

Tekst Exhortatio ad meditationem et conformationem passionis Christi zachował się w dwóch piętnastowiecznych rękopisach:

W $^{1}$ Wrocław, Biblioteka Uniwersytecka, I Q 42, f. $127 \mathrm{r}$ - 141r

$\mathrm{W}^{2}$ Wrocław, Biblioteka Uniwersytecka, I Q 104, f. 59r - 68v 
W wyniku przeprowadzonej krytyki tekstu za podstawę edycji przyjęto przekaz Exhortatio według rękopisu $\mathrm{W}^{1}$ wraz z poprawkami secunda manu. Warianty tekstowe umieszczono w aparacie naukowym. Ma on charakter negatywny, a zatem wskazuje miejsca, w których lekcje rękopisu $\mathrm{W}^{2}$ znacząco różnią się tych $\mathrm{z}$ rękopisu $\mathrm{W}^{1}$. Aby uzyskać większą przejrzystość, nie odnotowano w aparacie ewidentnych błędów i miejsc korekty secunda manu. W aparacie naukowym, obok uwag filologicznych, zasygnalizowano wszystkie źródła biblijne i pozabiblijne wskazane explicite przez autora. Niniejszą edycję sporządzono według zasad ortograficznych i interpunkcyjnych zaproponowanych i szeroko omówionych przez Tomasza Gałuszkę OP we wstępie do najnowszej edycji krytycznej Lectura super Matheum, autorstwa Tomasza z Akwinu' ${ }^{6}$.

W przekładzie tekstów biblijnych zastosowano: Pismo Święte Starego i Nowego Testamentu w przekładzie polskim w.o. Jakuba Wujka SJ. Kraków 1962.

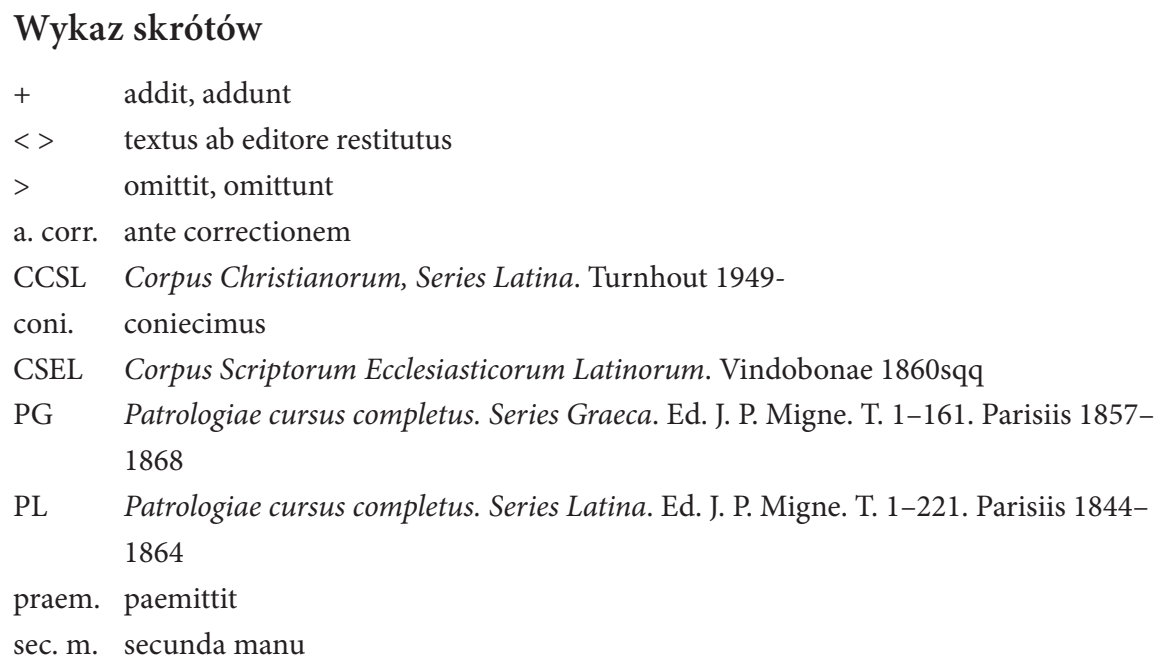

${ }^{6}$ T. Gałuszka, Tomasza $z$ Akwinu Lectura super Matheum cap. I-II. Studium historyczno-krytyczne i edycja tekstu. Kraków 2011, s. 174-178. 


\section{Matthias Hayn}

\section{Exhortatio ad meditationem et con- formationem passionis Christi}

'Conuertimini ad me in toto corde uestro in ieiunio et fletu et planctu et scindite corda uestra ${ }^{\mathrm{I}}$. Homo peccator et perditionis differt $a b$ homine iusto et felicitatis in hoc, quod homo peccator auertit se a Deo et delectatur in creaturis, quia ut dicit Augustinus 'Peccatum nihil aliud est quam auersio ab incommutabili bono ad bonum commutabile ${ }^{\text {II }}$. E conuerso homo iustus beatitudinem desiderans auertit se a delectatione creaturarum et conuertit se ad dilectionem creatoris. Hinc Paulus ait 'Omnia arbitratus sum ut stercora, ut Christum lucrifacerem ${ }^{\text {'III }}$. Hinc Deus noster cupiens nostram iustitiam et beatitudinem, quia ut dicitur I ad Thimoteum III 'Ipse uult omnes homines saluos facere ${ }^{\text {,V }}$ et 'Miseretur omnium et nichil odit eorum que fecit' Sapientie $\mathrm{XI}^{\mathrm{V}}$, sed potius ardentissime amat. Sic dicitur Jeremie XXXI 'In caritate perpetua dilexi te, ideo attraxi te ${ }^{\text {,VI }}$. Proprium autem est amantis esse cum amato. Hinc dicitur per prophetam Johelem in uerbis propositis 'Conuertimini ad me in toto corde uestro in ieiunio et fletu et planctu et scindite corda

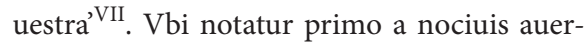
sio et ad utilisssimum et optimum applicatio. Ibi conuertimini ad me secundo notatur modus utilissime conuersionis, que debet esse quadruplex scilicet in toto corde in ieiunio in fletu et planctu et in contritione cordis seu

\section{Zachęta do rozważania i naśla- dowania Męki Chrystusa}

„Nawróćcie się do mnie ze wszystkiego serca waszego $\mathrm{w}$ poście i w płaczu i rozdzierajcie serca wasze”. Człowiek grzeszny różni się od sprawiedliwego zarówno ze względu na swój upadek, jak i szczęście tego drugiego, ponieważ grzesznik odwraca się od Boga i czerpie radość ze stworzeń, jak mówi św. Augustyn: „Grzech to nic innego, niż odwrócenie się od niezmiennego dobra ku dobru zmiennemu". Człowiek sprawiedliwy natomiast, pragnąc szczęścia, odwraca się od czerpania przyjemności ze stworzeń i zwraca ku umiłowaniu Stwórcy. Stąd św. Paweł: „Wszystko mam sobie za gnój, bylebym Chrystusa pozyskał". Dlatego Bóg, pragnąc naszej sprawiedliwości i szczęścia, jak powiedziane jest w Pierwszym Liście do Tymoteusza 3: „chce, aby wszyscy ludzie byli zbawieni” i w Księdze Mądrości 11: „Ma litość nad wszystkimi i nie ma w nienawiści nic z tego, co uczynił”, lecz jeszcze goręcej miłuje. Tak mówi Księga Jeremiasza 31: „Miłością wieczną umiłowałem cię, dlatego przyciągnąłem cię". Zatem obowiązkiem kochającego jest bycie z kochanym. Stąd wspomniane słowa proroka Joela: „Nawróćcie się do mnie ze wszystkiego serca waszego $\mathrm{w}$ poście i w płaczu i rozdzierajcie serca wasze". Po pierwsze oznaczają one odwrócenie się od rzeczy szkodliwych i przyłączenie się do najbardziej pożytecznych i najlepszych, po drugie zaś sposób najkorzystniejszego nawrócenia, 
compunctione. Toto corde id est pleno debemus conuerti ad diuina, qui fuimus uacui ab his, uel toto corde ne aliis rebus debemus participare, quia cor non totaliter est conuersum ad deum, quod habet aliquid cum eo. Per ieiunium strictissimum hoc tempore macerare debemus corpus, per cuius immoderantiam offendimus Deum. Per fletum et planctum hoc tempore placeamus Deo, quia per risum et kachinnos displicuimus. Cor etiam, quod induratum fuit peccatis, mollescat, ut conteri possit per compunctionem. Ista omnia melius habere non possumus, quam per Iesum Christum, qui ait 'Sine me nihil potestis $\left[\mathrm{W}^{1}\right.$ f. $\left.127 \mathrm{v}\right]$ facere ${ }^{\text {'VIII }}$. Et signanter per uenerande et amarissime passionis eius memoriam frequentem. Nam ut ait Frater Amandus in Horalogio Sapientie libro primo rubrica XIV 'Talis passionis memoria frequens indoctum reddit doctissimum et ydeotas facit proficere in magistros. Magistros inquam non sapientie, que inflat, sed caritatis, que edificat. Ipsa est uelut quidam liber uite, in quo omnia salutis necessaria inueniuntur ${ }^{\text {IX }}$. Ipsam igitur fratres karissimi diligenter legite, ut intellectus illuminetur. Ipsam diligentius meditamini, ut affectus in Christi amore inflammetur et ipsius passionis satagite diligentissime conformes fieri, ut perfectio operum attingatur. Lectio igitur fratres passionis Christi est bona, meditatio melior et conformatio optima. Meditatio enim Christi passionis inter alia bona duo affert scilicet tristitiam inordinatam repellit et penam porgatorii diminuit ${ }^{\mathrm{X}}$. Et quomodo hoc fiat pulcherrime declarat Frater Amandus libro et rubrica quibus supra in medio. Conformatio autem seu imitatio Christi passionis de qua ipse loquitur 'Om- które powinno być poczwórne, mianowicie: całym sercem, przez post, w płaczu i lamencie oraz przez ból i skruchę w sercu. „Całym sercem” oznacza, że w pełni powinniśmy nastawić się na sprawy boskie, my, którzy byliśmy ich pozbawieni, albo też „całym sercem”, czyli nie uczestnicząc w żadnych innych sprawach, ponieważ serce, które nie jest całkowicie zwrócone do Boga, nie ma z nim nic wspólnego. W tym czasie powinniśmy umartwiać surowym postem ciało, przez które nieumiarkowanie obrażamy Boga. Bądźmy mili Bogu, płacząc i lamentując, ponieważ śmiech i kpiny sprawiają $\mathrm{Mu}$ przykrość. Również serce zatwardziałe $\mathrm{z}$ powodu grzechów może zmięknąć, aby było w stanie doznać skruchy dzięki bólowi. Tego wszystkiego nie da się uzyskać w lepszy sposób niż przez Jezusa Chrystusa, który mówi: „Beze mnie nic uczynić nie możecie”, i oczywiście przez częste wspominanie Jego czcigodnej i najbardziej gorzkiej Męki. Mówi bowiem Frater Amandus w Horologium Sapientiae, w księdze pierwszej, w rozdziale XIV: „Częste wspominanie tej Męki nieuczonego czyni najlepiej wykształconym i sprawia, że głupcy stają się mistrzami. Nie chodzi tu o mistrzów mądrości, która nadyma, lecz miłości, która buduje. Jest ona jak księga życia, w której można odnaleźć wszystko, co konieczne”. Tę właśnie Bracia najdrożsi pilnie czytajcie, aby rozjaśniał się wasz umysł. Tę jeszcze pilniej rozważajcie, aby uczucia rozpaliły się w miłości do Chrystusa i troszczcie się najpilniej o stawanie się podobnymi do tej Męki, aby uzyskać ukończenie dzieł. Bracia, czytanie Męki Chrystusa jest więc dobre, rozważanie lepsze, a naśladowanie jej najlepsze. Rozważanie bowiem Męki Chrystusa przynosi dwie spośród wielu dobrych rzeczy: odpędza nieumiarkowa- 
nis qui uult uenire post me abneget semetipsum et tollat crucem suam et sequatur me $\mathrm{e}^{\text {XI }}$ et iterum Petrus Apostolus 'Christus passus est pro nobis, uobis relinquens exemplum, ut sequamini uestigia eius ${ }^{\text {'XII }}$ tam est acceptabilis Christo Domino, quam si quis in cruce $\left[\mathrm{W}^{2}\right.$ f. 59v] cum eo perstetisset et mortuus pariter cum ipso moriente fuisset. 'Hec est igitur crux, quam quilibet portare debet, si uult Christi esse amator'XIII ut dicit Frater Amandus ut supra rubrica XV. Crux igitur Christi super se recepta per diligentem et affectuosam imitationem similitudinariam ad Christi ueram passionem et realem reddit sic se conformantes acceptabiles Christo et amabiles, tristitiam repellit, penam porgatorii diminuit, peccata dimittit, gratiam augmentat et merita et ad gloriam eternam producit. 'Nullus enim' ut dicit Frater Amandus in Horalogio 'priuilegio spiritualis consolationis aut gratia superne uisitationis amplius gaudet, quam qui durissimas propter Christum tribulationes sustinet $^{\mathrm{XIV}}$. [W ${ }^{1}$ f. 128r] Hanc igitur passionem Christi durissimam fratres karissimi cordis brachiis constringite et in memoria habete et eam in cordibus scribite et ei quantum ualetis studeatis uos conformare ${ }^{\mathrm{XV}}$. Sed quia hec passio sanctissima est alta, profunda, lata et numerosa, nam Fratri Amando ostendebantur in extasi posito centum meditationes seu considerationes passionis Christi ${ }^{\mathrm{XVI}}$. Sed quia mens nostra fragilis simul multa comprehendere non potest, cogitaui, ut passionem Christi particulatim et punctatim singulis diebus per quadragesima quasi unicum morsellum uobis in mensa proponerem. Et si gratanter morsellum inter uos distributum acceptaueritis, quemadmodum fratres fecerunt ny smutek i zmniejsza karę czyśćca. Jak to się dzieje, najpiękniej przedstawia Frater Amandus w wyżej wspomnianym dziele $\mathrm{w}$ tymże rozdziale. Naśladowanie zaś lub podążanie za wzorem Męki, o której on sam mówi: „każdy, kto chce iść za mną, niech się sam siebie zaprze, i weźmie krzyż swój, a naśladuje mnie”, jak również Piotr Apostoł: „Chrystus za nas cierpiał, zostawiając wam przykład, abyście wstępowali w Jego ślady”, tak jest miłe Chrystusowi, jakby ktoś z Nim pozostawał na krzyżu i jednakowo z Nim samym umierał. „To zatem krzyż, który każdy powinien nieść, jeśli chce miłować Chrystusa”, jak mówi Frater Amandus, jak wyżej, w rozdziale XV. Przyjęcie krzyża Chrystusa przez staranne i oddane naśladowanie podobne do prawdziwej Męki czyni tak kształtujących się godnymi przyjęcia i miłymi Chrystusowi, odpędza smutek, zmniejsza karę czyśćca, odpuszcza grzechy, pomnaża łaskę i zasługi oraz prowadzi do wiecznej chwały. „Nikt bowiem”, jak mówi Frater Amandus w Horologium, „nie cieszy się przywilejem duchowego pocieszenia lub łaską boskiego objawienia bardziej, niż ten, który znosi najcięższe udręczenia $z$ powodu Chrystusa”. Zatem tę Mekę Chrystusa najtrudniejszą, bracia umiłowani, obejmijcie ramionami serca, miejcie $\mathrm{w}$ pamięci, zapiszcie sobie $\mathrm{w}$ sercach i starajcie się ją naśladować, na ile potraficie. Jednakże, ponieważ ta Męka najświętsza jest wysoka, głęboka, szeroka i obfita, gdyż Frater Amandus w ekstazie doznał objawienia stu rozważań lub rozmyślań o Męce Chrystusa, i ponieważ nasz słaby umysł nie może na raz pojąć wiele, pomyślałem, żeby przedstawić Mękę Chrytusa w częściach przez poszczególne dni Wielkiego Postu, jakby po jednym kawałku na stole. Jeśli chętnie kawałek między was rozdzielony 
tempore patris nostri Sancti Dominici, manus angelica $^{X V I}$ haud dubio a mentibus uestris omnem tollet inopiam ipsas plene reficiendo Christi ex influentia spiritualibus carismatibus. Primum ergo morsellum Christi passionis crastina die intendo proponere et sic consequenter per singulos dies quadraginte continuare, quem rogo ob salutem uestram gratanter saporoseque recipite in memoriam et meditationem et conformationem uite. Et sic in breui perficietis Dei gratia auxiliante in uiros alios et omnia laboriosa et amara in uita spirituali efficientur uobis leuia et suauia. Vnde Sapientie 'Audi fili mi et accipe consilium intellectus et ne abicies consilium meum, inice pedem tuum in conpedes illius scilicet passionis Christi et in torques illius collum tuum, subice humerum tuum et porta illam et ne accidieris in uinculis eius ${ }^{\mathrm{XVIII}}$. In nouissimis enim inuenies requiem in ea et conuertetur tibi in oblectationem ${ }^{\mathrm{XIX}}$. Modicum laborabis et inuenies multum requiem et delectationem ${ }^{\mathrm{Xx}}$. Quamquam enim caro exterius mortua appareat, intus tamen diuinitus lucet. Caro uidetur misera, sed latet qualis sit glorificata. Mundana autem et terrena foris dulcia et suauia apparent, intus autem uenena diffundunt. Talia igitur fratres karissimi summopere fugite et lignum uite, quod est crux Christi, tota diligentia mente et corpore amplectimini. Et sic cum Domino semper eritis nunc et secula seculorum. Amen. [ $\mathrm{W}^{1}$ f. $\left.128 \mathrm{v}\right]$

\section{Morsellus primus passionis Iesu Christi ${ }^{\mathrm{XXI}}$. Passio}

Iesus Christus Dei Filius imminente suo passione horrende ex consideratione in proximo przyjmiecie, jak bracia czynili w czasach ojca naszego Dominika, ręka anielska bez wątpienia zabierze $\mathrm{z}$ waszych umysłów wszelki niedostatek, wypełniając je dzięki Chrystusowi darami Ducha. Zatem pierwszy kawałek Męki Chrystusa mam zamiar przedstawić w jutrzejszym dniu i tak kontynuować kolejno przez poszczególne dni Wielkiego Postu. Proszę, abyście ze względu na wasze zbawienie łaskawie i ze smakiem przyjęli go do pamięci, rozważania i upodabniania życia. W ten sposób, dzięki Bożej łasce, w krótkim czasie staniecie się innymi ludźmi, a wszystko, co uciążliwe i gorzkie w życiu duchowym, stanie się lekkie i słodkie. Stąd w Księdze Mądrości: „Słuchaj, synu, i przyjmij radę rozumu, a nie odrzucaj rady mojej. Podaj nogę w pęta jej” to znaczy Męki Chrystusa „i szyję twoją w jej łańcuch; podłóż ramię twoje i noś ją, a niech ci się nie przykrzą jej więzy. Bo na końcu znajdziesz w niej odpocznienie i obróci ci się $\mathrm{w}$ wesele, trochę popracujesz, a odnajdziesz długi odpoczynek i radość". Chociaż bowiem ciało na zewnątrz wydaje się śmiertelne, w środku jednak jaśnieje z łaski Boga. Ciało wydaje się nędzne, lecz nie widać, jak jest wywyższone. Rzeczy materialne i ziemskie na zewnątrz wydają się słodkie i przyjemne, w środku zaś rozlewają truciznę. Takich więc, bracia najdrożsi, w najwyższym stopniu unikajcie i całą gorliwością, umysłem i ciałem obejmijcie drzewo życia, którym jest krzyż Chrystusa. Wtedy zawsze będziecie z Panem teraz i na wieki. Amen.

\section{Pierwszy kawałek Męki Jezusa Chrystusa. Passio} Jezus Chrystus syn Boga, kiedy zbliżała się Jego straszna Męka, rozmyślając o bliskości nadcho- 
superuenture mortis et diuersorum suppliciorum pre angustiis guttas saguineas sudando fundebat in terram. Tamen per hoc non fuit auersus, qui uoluntatem patris perficeret sustinendo crudelissimam passionem.

\section{Conformatio uite ad eandem ${ }^{\mathrm{XXII}}$}

Sic fratres karissimi opera ex lege Dei et uestra professione facienda hilariter perficite, etiam si uobis uideantur difficilia et nature esse multum contraria. Nulla enim difficultas operis, ex qua angustiatur sensualis homo et tristatur, postponere debet uoluntatem patris, sed potius semper debet se ei committere et conformare. Numquam $\left[\mathrm{W}^{2}\right.$ f. 60r] sensualibus est angustia et tristitia propriam uoluntatem non implere, pecuniis carere, castitatem corporis et anime integerrime tenere, die ac nocte Deo in choro seruire, carnem numquam comedere, colloquia propter silentium ad placitum non effundere, in stratu duro quiescere, salutem proximorum multiplici, laborem procurare. Sed si talis angustia uel tristitia uincatur et uoluntas Dei et sanctorum patrum impleatur, iam frater Christi imitator effectus est implens Christi beneplacitum. Nam ut dicit Fater Amandus 'Christus desiderat ortum nostrum id est cor nostrum inpinguari roseis floribus scilicet angustiis et tribulationibus ${ }^{\mathrm{XXIII}}$.

\section{Secundus}

\section{Passio}

Christus ${ }^{\mathrm{XXIV}}$ Dominus fuit captiuatus et uinculatus, ne quo uellet posset abire.

\section{Conformatio}

Sic quilibet frater captiuet seipsum, ne concupiscentia carnis ac sensualitatis appetitus dzącej śmierci i innych cierpieniach, z powodu przykrego położenia wylewał krwawe krople potu na ziemię. Jednak nie poddał się przez to ten, który wykonywał wolę Ojca, znosząc najokrutniejszą Mękę.

\section{Conformatio uite ad eandem [Upodabnianie życia do tejże]}

Tak, bracia najdrożsi, uczynki, wynikające z prawa boskiego i waszej profesji, z radością spełniajcie, nawet jeśli wydają się wam trudne i zupełnie przeciwne naturze. Żadna bowiem trudność działania, z powodu której człowiek wrażliwy jest gnębiony i smuci się, nie może umniejszać woli Ojca, lecz powinna się z nią łączyć i do niej upodabniać. Dla wrażliwych nigdy nie jest uciążliwe ani smutne niespełnianie własnej woli, ani życie bez pieniędzy, ani zachowywanie całkowitej czystości ciała i duszy, ani służenie Bogu w chórze w dzień i w nocy, ani niejedzenie mięsa, ani powstrzymywanie się od przyjemnych rozmów w czasie milczenia, ani wypoczywanie na twardym łożu, ani pomnażanie szczęścia bliźnich, ani dbałość o pracę. Lecz jeśli taka trudność lub smutek zostanie zwyciężony i wypełniona wola Boga i świętych ojców, natychmiast brat stanie się naśladowcą Chrystusa, gdyż działa według jego upodobania. Albowiem jak mówi Frater Amandus: „Chrystus pragnie upiększyć nasz ogród, to jest nasze serce, kwitnącymi różami czyli trudnościami i strapieniami”.

\section{Drugi \\ Passio}

Chrystus został schwytany i związany, aby nie mógł pójść tam, gdzie chce.

\section{Conformatio}

Tak każdy brat niech ujarzmi samego siebie, aby pożądliwość cielesna ani pragnienie zmy- 
ad nociua trahentem abiecto uinculo praceptorum liber prosequatur, quia talem libertatem concupiscentiarum sequitur mors ut patet Genesis tertio, ubi postquam Deus precepit Ade, ne comederet de ligno scientie boni et mali, mox subiunxit 'In quocumquam enim die ex eo comederis, morte morieris ${ }^{\mathrm{XXV}}$. Ex qua patet, quod abiectio uinculi preceptorum generat mortem. Captiuetur igitur et ligetur concupiscentia carnis et appetitus sensualitatis lege conscentie bone, que tunc bona est quando $\left[\mathrm{W}^{1}\right.$ f. 129r] congratulatur lege Dei ${ }^{\mathrm{XXVI}}$ ut dicit Damascenus libro IIII. Alias si homo liber delectetur in rebus sensualitati placentibus, ducitur ad transgressionem preceptorum ut patet exemplariter Genesis ut supra. Quando enim mulier uidit, quod bonum esset lignum ad uescendum et pulcrum occulis aspectu quoque delectabile, ecce delectatio sensualitatis tulit de fructu illius et comedit. Ecce precepti contemptus. Apprehensio igitur rei illicite tam sensus exterioris quam interioris est amputanda in principio, ne sibi fiat occasio ruine in peccatum. Et qualiter hoc fiat, declarat Albertus super Lucam capitulo IX, ubi ait 'Cogitatio allicit delectationem, delectatio trahit ad consensum, consensus autem querit qualiter perficiatur in opere et opus querit consuetudinem, consuetudo defensionem et defensio contemptum, contemptus autem minimi quod constitutum est $^{\text {XXVII }}$. Peccatum est mortale ${ }^{\text {XXVIII }}$ ut declarat Doctor Sanctus in Secunda Secunde questio 186 articulo primo. Huc usque cum Domino nostro in orto fuimus. słowości po odrzuceniu więzów przykazań nie podążało swobodnie za tym, co prowadzi do rzeczy szkodliwych, ponieważ za takim uwolnieniem pożądliwości idzie śmierć, jak mówi Księga Rodzaju, po tym jak Bóg przestrzegł Adama, aby nie jadł z drzewa poznania dobra i zła, natychmiast dodał: „bo którego dnia będziesz jadł z niego, śmiercią umrzesz". Z tego wynika, że odrzucenie więzów przykazań rodzi śmierć. „Niech więc pożądliwość cielesna i pragnienie zmysłowości zostaną ujarzmione i związane prawem dobrego sumienia, które wtedy jest dobre, kiedy cieszy się z prawa boskiego", jak mówi Jan Damasceński w ks. IV. $\mathrm{Z}$ drugiej strony jeśli człowiek wolny czerpie przyjemność w rzeczach bliskich zmysłowości, wiedziony jest do przekroczenia przykazań, co widać w Księdze Rodzaju, jak wyżej. Kiedy bowiem kobieta ujrzała, że drzewo jest dobre do spożywania, piękne dla oczu oraz dające radość, to właśnie przyjemność zmysłowa wzięła z jego owoców i zjadła. Oto lekceważenie przykazania. Podjęcie rzeczy zakazanej zarówno w znaczeniu zewnętrznym, jak i wewnętrznym powinno być odrzucone na początku, aby nie stało się sposobnością do popełnienia grzechu. Jak się to dzieje, ukazuje Albert w Super Lucam w rozdziale IX, gdzie mówi: „Myśl wabi przyjemność, przyjemność dąży do przyzwolenia, przyzwolenie zaś szuka, jak czyn może być popełniony, czyn szuka przyzwyczajenia, przyzwyczajenie obrony, a obrona lekceważenia, lekceważnie zaś w najmniejszym stopniu tego, co zostało postanowione". A jest to grzech śmiertelny, jak objaśnia Doctor Sanctus w Secunda Secundae w kwestii 186, w artykule 1. Do tego momentu byliśmy z naszym Panem w ogrodzie. 


\section{Tertius}

Passio

Dominus Iesus in qua nocte captus est in uia, qua ductus fuit in Ierusalem, et in domo Anne pontificis apertas iniurias, calumpnias, illusiones, contumelias, uerecundias illatas ab iniquis patienter sustinuit.

\section{Conformatio}

Sic frater quilibet omnia uerba contumeliosa, turbatiua, calumpniosa a malis et importunis hominibus illata patienter propter redemptionem suum sufferat. 'Frater tunc contumeliosus est, qui uerbis alium in audientia ipsius dehonestat ${ }^{\text {XXIX }}$ ut Doctor ${ }^{\mathrm{XXX}}$ Sanctus declarat ${ }^{\mathrm{XXXI}}$ in Secunda Secunde questio 72 articulo primo. Fratres sitis ergo cauti in uerbis contra proximum, ne incurratis peccatum contumelie Iudeorum, qui suis uerbis et factis intendebant Christum dehonestare. 'Quando enim’ ut dicit Doctor Sanctus ut supra articulo 2 intentio proferentis uerba contra proximum ad hoc fertur, ut honorem alterius auferet, hoc est peccatum mortale non minus quam furtum uel rapina. Non enim minus homo amat suum honorem quam rem possessam ${ }^{\text {XXXII }}$. Iudei etiam inferebant Christo calumpnias id est falsa crimina publice obiciebant ei. Sic frater facit, qui falsa crimina coram iudice imponit $\left[\mathrm{W}^{2} \mathrm{f} .60 \mathrm{v}\right]$ alteri. Nec in hoc excusat ignorantia a peccato, ut si imponerem falsum crimen alicui, quia putarem sic esse, quia 'homo non debet ad accusationem procedere nisi de re omnino sibi certa ${ }^{\text {XXXIII }}$ ut patet in Secunda Secunde questio 68 articulo 3 in solutione ad primum. [W $\mathrm{W}^{1}$ f. 129v]

\section{Trzeci}

\section{Passio}

Pan Jezus w nocy, której został schwytany, na drodze, którą był prowadzony do Jerozolimy i w domu kapłana Annasza cierpliwie zniósł jawne krzywdy, oszczerstwa, szyderstwa, obelgi i zniewagi wyrządzane przez niegodziwych.

\section{Conformatio}

Tak niech każdy brat wszystkie słowa obelżywe, wzburzające, oszczercze wypowiadane przez ludzi złych i zuchwałych niech cierpliwie znosi przez wzgląd na swoje zbawienie. „Brat wtedy dopuszcza się obrazy, gdy poniża innego słowami w jego obecności", jak mówi Doctor Sanctus w Secunda Secundae w kwestii 72, w artykule 1. Bądźcie więc bracia ostrożni $\mathrm{w}$ słowach przeciwko bliźniemu, abyście nie popadli w grzech zniewagi Żydów, którzy swoimi słowami i czynami starali się poniżyć Chrystusa. „Kiedy bowiem”, jak mówi Doctor Sanctus, jak wyżej, w artykule 2: „zamierzenie wypowiadającego słowa przeciw bliźniemu śpieszy do tego, aby odebrać mu cześć, stanowi to grzech śmiertelny nie mniejszy niż kradzież lub rabunek. Człowiek bowiem nie mniej kocha swoją cześć niż rzecz posiadaną". Żydzi także wysuwali przeciw Chrystusowi oszczerstwa, mianowicie publicznie zarzucali $\mathrm{Mu}$ nieprawdziwe przestępstwa. Tak czyni brat, który wobec sędziego zarzuca innemu nieprawdziwe przestępstwa. Niech nie będzie tu usprawiedliwieniem nieświadomość grzechu, jak gdybym zarzucał komuś fałszywy występek, gdyż uważałbym, że tak jest, ponieważ „nie wolno skarżyć, jeśli się nie ma pewności odnośnie do sprawy"XXXIV, co jest zawarte w Secunda Secundae w kwestii 68, artykule 3, w odpowiedzi na pierwszy. 
4

\section{Passio}

Dominus Iesus quando presentatus fuit Anne et stetit coram eo, innocens coram peccatore, interrogatur de duobus scilicet de doctrina et discipulis. De discipulis autem Christus omnino tacuit, de doctrina uero respondit.

\section{Conformatio}

Sic quilibet frater, quando iudicatur a prelato peiore, non debet ipsum contempnere, sed ad sibi proposita respondere. Quod etiam Dominus de discipulis tacuit, hoc ideo fuit, quia pro tunc non poterat de eis dicere nisi malum. Sic uos fratres karissimi malum proximi debetis subticere non solum falsum imponendo, sed nec peccatum occultum publicando, ubi non possumus proximo prodesse. Quod etiam Christus de doctrina dicens eam in publico esse factam, sic uos fratres fugite angulares informationes, quia signum doctrine sane et salubris est quando docetur aperte et in publico.

\section{5}

\section{Passio}

Dominus Iesus cum sic respondisset nephando Anne, unus assistens ministrorum dedit alapam ei dicens 'Sic respondes pontifici'. Respondit Iesus 'Si male locutus sum, testimonium perhibe de malo. Si autem bene, quid me cedis? ${ }^{\mathrm{XXXV}}$.

\section{Conformatio}

Sic uos fratres karissimi, si quis uos ex malis hominibus in faciem cedit, patienter debetis sufferre sine reprehensione et sine ira sicut Christus fecit seruo pontificis, quem potius instruxit de malo, ut ipsum cognosceret, quam ex inpatientia eum reprehensit. Sicut si quis uos percutet, sine transgressione pre-
4

\section{Passio}

Pan Jezus, kiedy został pokazany Annaszowi i stał przed nim, niewinny przed grzesznikiem, był pytany o dwie rzeczy, mianowicie o naukę i uczniów. Na temat uczniów Chrystus całkowicie milczał, o nauce zaś opowiedział.

\section{Conformatio}

Tak każdy brat, kiedy jest oskarżany przez złego przełożonego, nie powinien nim gardzić, lecz odpowiadać na postawione sobie zarzuty. Pan milczał na temat swoich uczniów, ponieważ wtedy mógłby o nich mówić tylko źle. Tak wy, bracia najdrożsi, powinniście milczeć o złu bliźniego, nie tylko obarczając się kłamstwem, lecz także nie wyjawiając ukrytego grzechu, gdy nie możemy pomóc bliźniemu. Ponieważ również Chrystus mówił o nauce, że była jawna, tak wy, bracia, unikajcie wiadomości niepotwierdzonych, ponieważ znakiem nauki zdrowej i pożytecznej jest to, że jest nauczana otwarcie i publicznie.

5

\section{Passio}

Kiedy Pan Jezus tak odpowiedział niegodziwemu Annaszowi, jeden pomocnik sług wymierzył Mu policzek, mówiąc: „Tak odpowiadasz najwyższemu kapłanowi?" Odpowiedział Jezus: „Jeżelim źle powiedział, daj świadectwo o złym; a jeśli dobrze, czemu mię bijesz?"

\section{Conformatio}

Tak wy, bracia najdrożsi, jeśli ktoś spośród złych ludzi uderza was w twarz, powinniście to cierpliwie znosić bez buntu i bez gniewu, jak Chrystus uczynił słudze kapłana, którego bardziej pouczył o złu, aby je rozpoznał, niż zganił go z niecierpliwości. Tak jeśli ktoś was uderzy, bez przekraczania wskazania o nadstawianiu drugiego policzka 
cepti de exhibitione alterius maxille possetis dicere 'Fili male facis et excommunicationem incurris, cum sim sacerdos uel clericus in sacris constitutus', quia illud preceptum prebet $^{\mathrm{XXXVI}}$ ei et aliam non prohibet nisi iram et uindictam. Alapa datur ad maxillam manu, qua maxille coniuguntur labiis et ori. Sic fratres debemus alapizare uerba otiosa, praua et mendosa penitus excludendo. Nam sic seruus pontificis os ueritatis alapizauit, in quo non est inuentum dolus nec mendacium. Sic nos debemus Christo conformari in uerbis ueritatis omnem dolum excludendo. Modo eximus de domo Anne cum Domino Nostro ad domum Cayphe.

6

\section{Passio}

Christus Iesus ductus est demane de domo Anne, in qua erat per noctem ad Caypham pontificem ligatus. Et ab ipso coram scribis et senioribus et summis sacerdotibus fuit examinatus et quando adiuratus fuit a Caypha, [W ${ }^{1}$ f. 130r] ut diceret si ipse esset Christus filius Dei Benedicti, Iesus fatebatur ueritatem dicens 'Ego sum'XXXVII.

\section{Conformatio}

Sic fratres karissimi sicut Dominus Noster fuit ductus ad Caypham pontificem acutum iudicem, qui examinauit eum de multis, ita uos debetis singulis diebus et spiritualiter in nocte adducere ad iudicem uestrum, qui est conscientia uestra, ut ipsa examinet diligenter et ueraciter facta a uobis in precedente die, utrum fuerint bona uel mala, deifica uel dyabolica, religiosa uel irreligiosa id est si fuerint ${ }^{\text {XxxvIII }}$ facta secundum regulam et constitutiones uestras uel możecie powiedzieć: „Synu źle czynisz i ściągasz na siebie ekskomunikę, ponieważ jestem kapłanem lub klerykiem ustanowionym do rzeczy świętych"; ponieważ owo wskazanie na to pozwala i nie zabrania niczego, chyba że gniewu i zemsty. Policzek wymierza się ręką, a policzki są połączone z wargami i ustami. Tak bracia powinniśmy policzkować słowa niepotrzebne, przewrotne i kłamliwe, całkowicie je usuwając. Albowiem w ten sposób sługa spoliczkował usta prawdy, w których nie został odnaleziony podstęp ani kłamstwo. Tak my powinniśmy upodabniać się do Chrystusa w słowach prawdy, odrzucając wszelki podstęp. Teraz z Panem Naszym przechodzimy z domu Annasza do domu Kajfasza.

\section{6}

\section{Passio}

Związany Chrystus Jezus został przeprowadzony z domu Annasza, w którym był przez noc, do kapłana Kajfasza. Był przez niego przesłuchiwany wobec pisarzy, starszych i najwyższych kapłanów, a kiedy Kajfasz zaklinał Go, aby powiedział, czy sam jest Chrystusem synem Boga błogosławionego, Jezus wyznał prawdę, mówiąc: "Jam jest".

\section{Conformatio}

Tak, bracia najdrożsi, jak Pan nasz został zaprowadzony do kapłana Kajfasza, przenikliwego sędziego, który wypytywał Go o wiele, tak wy powinniście codziennie duchowo przychodzić w nocy do waszego sędziego, którym jest wasze sumienie, aby samo wypytało was dokładnie i szczerze o czyny z poprzedniego dnia, czy były dobre, czy złe, boskie czy diabelskie, zakonne czy niezakonne, to znaczy czy zgodne z waszą regułą i konstytucjami, czy im przeciw- 
si fuerint eis contraria. Et sicut bonus iudex innocentes dimittit et conseruat in uita, malos autem et reos dampnat et interficit $\left[\mathrm{W}^{2} \mathrm{f}\right.$. $\left.61 \mathrm{r}\right]$ eos penitus exterminando, sic uos opera bona regularia et constitutionalia debetis conseruare, uiuificare et continuare, mala autem facta, que semper sunt pena digna penitus exterminare et a uobis excludere. 'Et religiosus, qui tale examen bone conscientie dimiserit et manserit in sua tepiditate, uanitate et carnalitate, sequens plus suam uanitatem quam regule uel constitutionis, miserabilior quodammodo est omnibus creaturis carens Deo et mundo XXXIX ut dicit Frater Amandus in Horalogio libro II rubrica VI. Et conditiones talium malorum religiosorum sunt ut idem ibidem subiungit 'proteruia contra suos subperiores, querolositas id est qui nichil uult sustinere, sed sue uoluntate uiuere, cupiditas rerum temporalium inordinata et laxatio freni nimis libera ad circumstantias peccati carnalis'. Et post pauca subiungit 'in seruitio Dei sunt pigri, in questu temporalium solliciti et omni tempore circa curam corporis nimis intenti. Et plures subiungit ibidem, que possunt legi ibidem. Sed hic solam finalem condicionem subiungam, quia tales uani religiosi habent cor mundanis desideriis repletum, et si qua habent parua bona, multis tamen malis sunt permixta. Sicut etiam Christus coram iudice ueritatem non deseruit, sed ueritatem confessus fuit, sic uerus religiosus propter nullum temporale periculum debet deserere ueritatem, sed usque in mortem constans perdurare. ne. I tak jak dobry sędzia niewinnych uwalnia i zachowuje przy życiu, złych zaś i winnych potępia i zabija, wyniszczając ich całkowicie, tak wy powinniście uczynki dobre wobec reguły i konstytucji zachowywać, ożywiać i wciąż czynić, złe zaś uczynki, które zawsze są godne kary, wyniszczać całkowicie i usuwać z siebie. „Zakonnik, który porzuci takie badanie dobrego sumienia i pozostanie w swoim umiarkowaniu, próżności i cielesności, podążając bardziej za swoją próżnością niż regułą i konstytucjami, jest poniekąd bardziej nieszczęśliwy, niż wszystkie stworzenia - brakuje mu Boga i świata”, jak mówi Frater Amandus w Horologium w księdze 2, rozdziale 6 . A położenie tych złych zakonników jest takie, jak opowiada on w tym samym miejscu: „Zuchwałość wobec przełożonych, narzekanie, to znaczy niechęć do znoszenia czegokolwiek, lecz życie zgodnie własną wolą, nieumiarkowane pożądanie rzeczy doczesnych, zbytnie «popuszczenie uzdy» wobec sposobności popełnienia grzechu cielesnego". I trochę dalej dodaje: „w służbie Bogu są leniwi, zatroskani zyskiwaniem dóbr doczesnych i wciąż zbyt oddani trosce o ciało", a także wiele innych, które można tam przeczytać. Lecz tutaj dołączę jedyną ostatnią okoliczność, że serce takich próżnych zakonników wypełniają ziemskie pragnienia, a jeśli w jakiś sposób mają oni $<$ w sobie $>$ pewne dobre rzeczy, mimo to są one zmieszane z wieloma złymi. Tak jak Chrystus wobec sędziego nie odstąpił od prawdy, lecz prawdę wyznał, tak prawdziwy zakonnik nie powinien porzucać prawdy z powodu żadnego doczesnego niebezpieczeństwa, lecz wytrwać w stałości aż do śmierci. 
7

\section{Passio}

Iesus Christus cum staret coram Caypha, principes $^{\mathrm{XL}}$ sacerdotum et omne [ $\mathrm{W}^{1}$ f. 130v] concilium querebant falsum testimonium contra eum, ut eum morti tradent. Et nouissime surrexerunt duo falsi testes, qui asseruerunt ipsum dixisse, quod templum Dei manufactum posset destruere et in triduo illud reedificare et per hoc conabantur probare, quod ipse diuinam potentiam sibi usurpasset. Sed fuerunt falsi testes, quia uerba Christi mutabant, que fuerunt hec 'Soluite templum hoc et in tribus diebus excitabo illud'XLI significans templum corporis sui.

\section{Conformatio}

Sic uos fratres karissimi potius cum Christo sustinete falsum testimonium perhibitum contra uos, quam quod cum Iudeis falsissimis uelitis falsum testimonium perhibere de aliquo. Nam ut dicit Ysidorus in libro de summo bono 'Testis falsidicus tribus personis est obnoxius: primo Deo, quem periurando contempnit, consequenter iudici, quem mentiendo fallit, postremo innocenti, quem falso testimonio ledit ${ }^{\text {XLII }}$. Et ne Christum cum Iudeis morti tradamus, quia mendaciis et fallaciis ad mortem deductus fuit, falsum testimonium immo omnem falsitatem et mendacium summe detestemur.

8

\section{Passio}

Dominus Iesus quando non potuit conuinci falso testimonio ad condempnationem mortis, turbatus est summus pontifex Cayphas et adiurauit Iesum, ut diceret sibi, si ipse esset Christus filius Dei. Et postquam Dominus respondisset
7

\section{Passio}

Kiedy Jezus Chrystus stał przed Kajfaszem, pierwszymi kapłanami i całym zgromadzeniem, oni szukali fałszywego świadectwa przeciw Niemu, aby Go posłać na śmierć. Wreszcie wstali dwaj fałszywi świadkowie, którzy stwierdzili, iż powiedział, że świątynię Boga zbudowaną rękami może zniszczyć i w trzy dni odbudować, przez co próbowali wykazać, że przywłaszczył sobie moc Bożą. Lecz byli oni fałszywymi świadkami, gdyż przemilczeli słowa Chrystusa: „Rozwalcie tę świątynię, a w trzech dniach ją postawię" oznaczające świątynię Jego ciała.

\section{Conformatio}

Tak, bracia najdrożsi, lepiej znosić z Chrystusem fałszywe świadectwo przeciwko wam składane, niż chcieć składać je przeciwko komuś z kłamliwymi Żydami. Albowiem jak mówi Izydor w Księdze o najwyższym dobru: „Fałszywy świadek szkodzi trzem osobom: po pierwsze Bogu, którego znieważa krzywoprzysięstwem, następnie sędziemu, którego kłamstwem zwodzi, na koniec niewinnemu, którego krzywdzi fałszywym świadectwem". I abyśmy z Żydami nie posyłali Chrystusa na śmierć, ponieważ był prowadzony na śmierć kłamstwami i zdradą, odrzućmy zupełnie fałszywe świadectwo, wszelki fałsz i kłamstwo.

\section{8}

\section{Passio}

Skoro przy pomocy fałszywego świadectwa nie udało się doprowadzić do skazania Pana Jezusa na śmierć, najwyższy kapłan Kajfasz zaniepokoił się i zaklinał Go, aby powiedział, czy jest Chrystusem, synem Boga. I po tym, jak Pan 
ueritatem dicendo 'Ego sum ${ }^{\text {XLIII }}$, imposuit sibi detestabile crimen blasphemie. Quod ita detestabile fuit apud Iudeos, quod ad eius auditum uestimenta scinderent.

\section{Conformatio}

Sic fratres si aliquando contingat uos blasphemari uel maledici $\left[\mathrm{W}^{2}\right.$ f. $61 \mathrm{v}$ ] ab hominibus, qui sunt met blasphemi et maledictione digni, tamen non debetis eos econtra blasphemare et maledicere. Numquam Christus, cui blasphemia iniuste imponebatur, ad Caypham dicere potuisset 'Non ego sed tu blasphemus es, qui Deum mortalem intendis facere'. Sed hoc non dixit, immo calumpniam patienter sustinuit, ne per os suum aliquod uerbum exiret blasphemie nobis in exemplum. Similiter nec angelus dyabolum blasphemare uoluit. Vnde legitur in Exempla Iude 'Quando Michael archangelus altercaretur cum dyabolo de Moysi corpore, non est ausus iudicium blasphemie inferre dyabolo, sed dixit: Imperet tibi Deus' ${ }^{\text {XLIV }}$. Ad cuius exemplum nec heretici nec quisquam malus homo maledicendi sunt, sed sermone modesto, [ $\mathrm{W}^{1}$ f. $131 \mathrm{r}$ ] doctrinali et pacifico corripiendi sunt. Quia licet in eis uoluntas sit praua, tamen natura est bona et a Deo creata et sic creatori in creatura parcendum est.

\section{9}

\section{Passio}

Dominus Iesus postquam calumpniam blasphemie patienter sustinuisset sibi iniuste impositam, dixit Cayphas ad summos sacerdotes et ad omne consilium 'Quid uobis uidetur?', qui omnes responderunt 'Reus est mortis ${ }^{\text {XLV }}$. Quod uerum fuisset si Iesus blasphemiam dixisset, quia tales debebant lapidari ${ }^{\mathrm{XLVI}}$ secundum Legem Leuitici XXIIII. Sed quia Dominus odpowiedział, mówiąc prawdę: „Jam jest”, zarzucił mu haniebne bluźnierstwo. Dla Żydów było to tak haniebne, że na te słowa rozdarli szaty.

\section{Conformatio}

Tak bracia, jeśli kiedykolwiek zdarzy się wam być przeklinanymi lub znieważanymi przez ludzi, którzy sami są godni przekleństwa i zniewagi, mimo to nie powinniście w odwecie przeklinać ich i znieważać. Chrystus, któremu niesłusznie zarzucano bluźnierstwo, nigdy nie mógłby powiedzieć do Kajfasza: „Nie ja, lecz ty, który Boga próbujesz czynić śmiertelnym, jesteś bluźniercą”. Jednakże tego nie powiedział, a nawet cierpliwie zniósł zniewagę, aby z Jego ust nie wyszło jakieś słowo złorzeczenia stanowiące przykład dla nas. Podobnie anioł nie chciał złorzeczyć diabłu. Dlatego czytamy w Exempla Iudae: „Gdy Michał $\operatorname{archanioł~} \mathrm{z}$ diabłem rozprawiając, spierał się o ciało Mojżesza, nie śmiał rzucić zelżywego wyroku, ale rzekł: «Niech tobie Pan rozkaże»". Za tym przykładem ani heretycy, ani żaden zły człowiek nie powinien być znieważany, lecz upominany mową skromną, uczoną i pokojową. Ponieważ choćby była w nich zła wola, natura jednak jest dobra, stworzona przez Boga i tak Stwórca powinien oszczędzać stworzenie.

9

\section{Passio}

Po tym, jak Pan Jezus cierpliwie zniósł niesłusznie wniesione oskarżenie o bluźnierstwo, Kajfasz przemówił do najwyższych kapłanów i całego zgromadzenia: „Co się wam zdaje?” Wszyscy odpowiedzieli: „Winien jest śmierci”. To byłoby prawdą, gdyby Jezus wypowiedział bluźnierstwo, gdyż tacy powinni być ukamienowani zgodnie z Prawem Lewickim 24. Po- 
Iesus blasphemus non fuit, ideo condempnatio prouana et iniqua fuit et inter puncta seu morsellos passionis ponenda.

\section{Conformatio}

Sic fratres karissimi quilibet recogitet qualiter propter peccata sua reum sepius se mortis fecerat, sed Dei misericordia sit hactenus conseruatus pro sua emendatione. Nam de quocumque existente in peccato mortali uerum est dicere 'Reus est mortis'. Hec enim mala sequuntur peccatum ut dicit Frater Amandus in Horalogio libro 2 rubrica VI 'Seua penitentia, gemitus et fletus cordis, tristitia, clamor atque miseria. Deus perditur, anima misera a summo bono separatur, gratiis nudatur ac donis celestibus spoliatur, confusione induitur, ignominia repletur, decipitur, derelinquitur et quodammodo bonis omnibus priuatur. Remorsu proprie conscientie cruciatur, uiuens moritur ac sanus existens languidus efficitur. occulos sprituales eruit, Spiritum Sanctum fugat et robur omne tollit. Inde animus amaricatur et denique omnis creatura tormentum eius efficitur'XLVII.

10

\section{Passio}

Dominus Iesus Christus etiam a Iudeis sustinuit colaphos id est percussiones in collo et hoc in eius paruipensionem. Solent enim fatui et despectabiles persone percuti in collo.

\section{Conformatio}

Sic frater quilibet in secreto possit sibi dare colaphum in commemorationem colaphorum Christi, quos in mente reuoluet. Nam non tantum Christum sequi debemus spiritualiter, sed etiam, ubi possumus, corporaliter ut uidelicet nieważ jednak Pan Jezus nie był bluźniercą, tę bezbożną oraz niegodziwą zniewagę należy umieścić wśród kawałków Męki.

\section{Conformatio}

Tak, bracia najdrożsi, niech każdy zastanawia się, jak z powodu własnych grzechów czyni siebie często winnym śmierci, lecz dzięki Bożemu miłosierdziu jest już ocalony stosownie do swojego nawrócenia. Albowiem o każdym trwającym w grzechu ciężkim godzi się powiedzieć: „Winny jest śmierci”. Takie bowiem złe następstwa podążają za grzechem, jak mówi Frater Amandus w Horologium w księdze 2, rozdziale 6: „Wielki żal, jęk i płacz serca, smutek, krzyk i udręka. Traci się Boga, nieszczęśliwa dusza jest oddzielana od najwyższego dobra, pozbawiana łask i ogołacana z dóbr niebieskich, wdziewa zakłopotanie, napełnia się niesławą, oszukuje się, jest opuszczona i w pewien sposób pozbawiona wszystkich dóbr. Jest dręczona niepokojem własnego sumienia, żyjąc umiera i pozostając zdrowa, staje się znużona. Wyłupia oczy duchowe, unika Ducha Świętego i odbiera wszelką siłę. Dlatego duch gorzknieje i w końcu każde stworzenie staje się dla niej torturą".

10

\section{Passio}

Pan Jezus również od Żydów przyjął ciosy, czyli uderzenia w kark, i to dla swojego poniżenia. Zwykle bowiem osoby głupie i wzgardzone są uderzane w kark.

\section{Conformatio}

Tak każdy brat w ukryciu może uderzać się na pamiątkę uderzeń wymierzonych Chrystusowi, które trzeba rozważać w duchu. Albowiem naśladować Chrystusa powinniśmy nie tylko duchowo, lecz także, kiedy możemy, fizycznie, mianowicie: 
sicut Ipse ieiunabat, nos ieiunare debemus et sicut Ipse oratione genua flectebat, sic et nos facere debemus et sicut ipse fatigatus fuit in uia, ita et nos debemus fatigari propter ipsum etc. Sed multi fratres non seipsos colaphizant sed Christum. Nam ut Beda dicit 'Colaphizant omnes Christum falsi christiani, qui ore confitentur [ $W^{2}$ f. 62r] Christum, factis [ $W^{1}$ f. 131v]

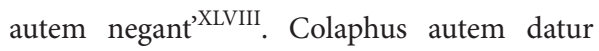
a retro. Illi ergo colaphizant Dominum, qui ante ei blandiuntur ore fidem confitendo, sed retro, quo deberent eum sequi per bona opera, faciunt mala opera Christo contraria, sicut uani religiosi dum sunt in choro ante Dominum, qui ibi est in sacramento, ipsum ore laudant diuinum officium in missa et in horis persoluentes, sed quando sunt retro in conuentu, os eorum repletur amaritudine et maledictione et dolo, murmurando, detrahendo, temerarie iudicando, contentendo, cachinnos et uerba otiosa per totum diem multiplicando, facta religiosa si insurgant, in pugnando et contradicendo. Tamen potius ori suo deberent ponere custodiam, cum eos dyabolus in talibus temptaret, et se ab otiositate ad scripturas sacras deberent se $\mathrm{e}^{\mathrm{XLIX}}$ conuertere, ubi inuenirent, quid agere et cauere deberent. Hinc Ieronymus suadet sancte uirgini Eustochio 'Crebrius lege, disce quam plurima et usque ad sompnium tene codicem ${ }^{\mathrm{L}}$.

\section{1}

\section{Passio}

Dominus Iesus deinde sputis immundis in sua facie ab impiis Iudeis fuit fedatus in suum uituperium et despectum. Quando enim pater alicuius puelle expuisset ${ }^{\mathrm{LI}}$ in eius faciem, ita abhominabilis reddebatur, ut sequestraretur septem diebus ab hominibus. tak jak On sam pościł, my powinniśmy pościć, jak On sam klęczał na modlitwie, my powinniśmy czynić, jak On sam był znużony w drodze, tak i my powinniśmy trudzić się z Jego powodu etc. Tymczasem wielu braci nie uderza siebie samych, lecz Chrystusa. Albowiem, jak mówi Beda: „Policzkują Chrystusa wszyscy fałszywi chrześcijanie, którzy ustami wyznają, a czynami zaprzeczają". Uderzenie w kark wymierza się od tyłu. Ci więc uderzają Pana, którzy z przodu, schlebiają $\mathrm{Mu}$ wyznając ustami wiarę, a z tyłu, tam, gdzie powinni naśladować Go przez dobre uczynki, czynią złe, przeciwne Chrystusowi. Tak jak próżni zakonnicy, kiedy są w chórze przed Panem, który jest w sakramencie, chwalą Go ustami, wypełniając oficjum w czasie godzin i mszy, lecz kiedy są z tyłu w konwencie, ich usta wypełniają się goryczą, złorzeczeniem, podstępem, szemraniem, poniżaniem, lekkomyślnym osądzaniem, kłótniami, śmiechami i zbędnymi słowami powtarzanymi przez cały dzień. Jeśli przykładają się do czynów pobożnych, to tylko $z$ walką i sprzeciwem. Jednak powinni raczej postawić straż przy swoich ustach, kiedy diabeł ich do tego kusi, i powinni od bezczynności zwrócić się do Pisma Świętego, gdzie odnajdą to, co należy czynić i czego się wystrzegać. Dlatego Hieronim doradza świętej dziewicy Eustochium: „Częściej czytaj, ucz się jak najwięcej i trzymaj książkę aż do uśnięcia”.

\section{1}

\section{Passio}

Następnie bezbożni Żydzi splamili twarz Pana Jezusa nieczystą śliną, aby Go obrazić i znieważyć. Kiedy bowiem ojciec pewnej dziewczynki splunął na jej twarz, stała się tak okropna, że ludzie unikali jej [dziewczynki] siedem dni. 


\section{Conformatio}

Sic fratres sumopere caueamus, ne Christi faciem cum Iudeis conspuamus, quod sit uno modo secundum Ieronimum, quando conscientia uniuscuiusque fedis operibus polluitur. Alio modo faciem Christi conspuunt secundum Gregorium, qui iustos et sanctos in presenti uita contumeliis afficiunt ${ }^{\mathrm{LII}}$. Tertio modo in faciem Christi conspuunt, qui eukaristiam indigne sumunt. Nam saliua sua peccato infecta sacramentum contingunt, madefaciunt et degluttiunt. De quibus Saluator dicere potest 'Faciem meam conspuere non uerentur' ${ }^{\text {'LIII }}$ Iob XXX. Conformet autem se frater consputioni faciei Christi in hoc, quod format sibi Christum tam horribiliter sputis deturpatum in mente sua et regratietur sibi, qui ipse in faciem conspui uoluit, ut nos lauaret ${ }^{\mathrm{LIV}}$ ut Ieronymus dicit. Et gloriemur in hoc, quod tam exprobratissime Dominus noster pro nobis pati uoluit. Precogitet etiam unusquisque quotiens ipse faciem conscientie sue, que est ymago Christi sputis peccatorum polluerat. Item quotiens indigne communicando sputi sui contactu faciem Christi sordidauerit.

\section{2}

\section{Passio}

Domino Iesu Christo palmas dederunt in faciem iniqui Iudei et extensis $\left[\mathrm{W}^{1} \mathrm{f}\right.$. 132r] manibus faciem eius percusserunt et possibile fuit, quod ex tali percussione fluxerit sanguis per nares et os, quamuis hoc Euangeliste non memorentur seu ponant.

\section{Conformatio}

Sic fratres karissimi patienter sustinete, si quis uos in faciem cedit uel corporaliter sicut Christus fuit cesus in faciem, sed etiam spiritualiter. Nam in faciem ceditur spiritualiter in cuius

\section{Conformatio}

Tak, bracia, usilnie strzeżmy się, abyśmy nie pluli z Żydami na twarz Chrystusa, co po pierwsze według Hieronima ma miejsce, kiedy czyjeś sumienie jest kalane brudnymi uczynkami. Po drugie twarz Chrystusa według Grzegorza opluwają ci, którzy na tym świecie znieważają świętych i sprawiedliwych. Po trzecie na twarz Chrystua plują ci, którzy niegodnie przyjmują Eucharystię. Albowiem swoją śliną skalaną grzechem dotykają, zwilżają i połykają sakrament. Zbawiciel może o nich powiedzieć: „nie wstydzą się pluć na oblicze moje” ks. Hioba 30. Brat zaś w ten sposób naśladuje opluwanie twarzy Chrystusa, że tworzy sobie w umyśle Chrystusa tak strasznie zeszpeconego śliną i dziękuje temu, którego twarz była opluwana, abyśmy zostali obmyci, jak mówi Hieronim. I chlubmy się tym, że Pan nasz w tak wielkiej hańbie zechciał za nas cierpieć. Niech każdy także rozważy, ile razy splamił śliną grzechów twarz swojego sumienia, która jest wizerunkiem Chrystusa, a także ile razy przyjmując niegodnie komunię, dotykiem swojej śliny skalał twarz Chrystusa.

\section{2}

\section{Passio}

Niegodziwi Żydzi policzkowali Pana Jezusa i wyciągniętymi rękami uderzali Jego twarz i możliwe było, że z powodu takiego uderzenia krew popłynęła przez nos i usta, chociaż ewangeliści o tym i nie wspominają ani tego nie podają.

\section{Conformatio}

Tak, bracia najdrożsi, cierpliwie znoście, jeśli ktoś uderza was w twarz zarówno fizycznie, jak bity był Chrystus, jak również duchowo. $\mathrm{W}$ twarz bowiem uderzany jest duchowo ten, 
os id est potentia iniuria irrigatur ${ }^{\mathrm{LV}}$ ut dicit glosa. Caueamus etiam, ne et nos demus palmam in faciem Christi. Illi enim dant palmas in faciem Christi, qui integritatem diuine ymaginis in mente sua ledunt et $\left[\mathrm{W}^{2}\right.$ f. $\left.62 \mathrm{v}\right]$ offendunt. Ymago Dei est in potentiis anime rationalis. Nam memoria est similis Patri, intelligentia Filio et uoluntas Spiritui Sancto. Et hec ymago quando peccatis se inuoluit, ymaginatum offendit id est Patrem et Filium et Spiritum Sanctum. Item in faciem Christi palmas dant illi sacerdotes, qui pollutis manibus per luxuriosos contactus corpus Christi contrectant.

\section{3}

\section{Passio}

Iesu Christi faciem Iudei uelauerunt, quem prophete inspicere desiderabant.

\section{Conformatio}

Sic fratres nolite cum Iudeis faciem Christi uelare, sed potius recogitate omnia nuda et aperta esse occulis eius et sic retrahatis uos a peccatis. Et secundum Ieronymum 'Christus Dominus pro nobis uoluit uelari ${ }^{\mathrm{LVI}}$, ut uelamen culpe et ignorantie a cordibus nostris auferret ${ }^{\text {LVII }}$. Et illud uelamen culpe et ignorantie representat uelamen quadragesimale, quod in Christi passione scissum est. Nam culpa tenebras adducit secundum illud 'Qui male agit, odit lucem' ${ }^{\text {LVIII }}$. Passio autem Christi recepta in imitatione adducit lucem. Secundum illud 'Qui sequitur me non ambulat in tenebris, sed habebit lumen uite $^{\text {LIX }}$. Peccatores igitur uelant faciem Christi ambulantes in tenebris peccatorum. Aliqui in proprietate ut religiosi, aliqui in rebellione ut proterui, aliqui in factis luxuriosis quasi ista essent abscondita ab occulis Dei. na czyją twarz wylewana jest niesprawiedliwość, jak mówi glosa. Strzeżmy się również, abyśmy i my nie uderzali w twarz Chrystusa. Ci bowiem policzkują Chrystusa, którzy w duchu obrażają i znieważają nienaruszoność wizerunku Chrystusa. Wizerunek Boga jest we władzach duszy rozumnej. Albowiem pamięć jest podobna do Ojca, rozum do Syna, a wola do Ducha Świętego. I kiedy ten wizerunek jest otoczony grzechami, znieważa wyobrażanego, czyli Ojca, Syna i Ducha Świętego. Podobnie policzkują Chrystusa ci kapłani, którzy dotykają ciała Chrystusa dłońmi zhańbionymi stycznością ze zbytkiem.

13

\section{Passio}

Żydzi zasłonili twarz Jezusa Chrystusa, którą pragnęli ujrzeć prorocy.

\section{Conformatio}

Tak, bracia, nie zasłaniajcie z Żydami twarzy Chrystusa, lecz raczej przypomnijcie sobie, że wszystko jest odkryte i odsłonięte przed Jego oczami i tak powstrzymujcie się od grzechów. Według Hieronima: „Chrystus Pan dla nas chciał być zakryty, aby odsunąć zasłonę winy i niewiedzy od naszych serc". I tę zasłonę winy i niewiedzy zastępuje zasłona wielkopostna, która została rozdarta w czasie Męki Pańskiej. Albowiem wina powoduje ciemności, zgodnie $\mathrm{z}$ wersetem: „który źle czyni, nienawidzi światłości”. Męka zaś Chrystusa przyjęta do naśladowania sprowadza światło. Dlatego: „kto za mną idzie, nie chodzi w ciemności, ale będzie miał światłość życia”. Grzesznicy więc zasłaniają twarz Chrystusa, błądząc w ciemnościach grzechu. Jedni w bogactwie, jak zakonnicy, inni w buntach, jak zuchwalcy, jeszcze inni w czynach rozpustnych, jakby były one ukryte przed oczami Boga. 
14

Passio

Postquam Iudei faciem Iesu Christi uelauerunt, percusserunt eum aliqui in maxillam, aliqui in collum dicentes 'Prophetisa nobis, quis te percussit $^{\text {LX }}$.

\section{Conformatio}

Sic quilibet frater conpatiendo Christo recogitet irrisionem et infamationem, quam Dominus in hoc facto passus est et quomodo Iudei de ipso ludum fecerunt quasi de puero. Nec temptemus eum prophetiam seu experientiam ab eo expectando et spiritualiter in his, que sunt fidei. Nec remittat se frater super hoc, quod iam peccata $\left[\mathrm{W}^{1}\right.$ f. 132v] dissimulat Christus quasi habens faciem uelatam, quia cum arripuerit iudicium, manus eius reddet ultionem hostibus suis. Et frater quilibet omnem penam temporalem sustinere deberet, antequam occulos iudicis Christi offenderet. Hinc frater Christum extreme flagitet timens horrendam uisionem Christi modo uelatam, sed in iudicio reuelandam dicens 'Fac mihi Domine Iesu in hoc tempore quidquid tibi placuerit. Impone leges, adauge tribulationes, aduersantes multiplica, infirmitates centuplica, quidquid tibi placuerit libentissime feram, hoc solum supplicans, ut a facie furoris tui michi parcere digneris ${ }^{\mathrm{LXX}}$. Modo exeamus cum Domino Nostro iniuriosam domum Cayphe pontificis.

15

\section{Passio}

Postea mane quasi hora prima ductus est Dominus Iesus a multitudine Iudeorum de domo Cayphe in pretorium et uinctus presentatus est Pontio Pilato presidi.
14

\section{Passio}

Po tym, jak Żydzi zasłonili twarz Jezusowi, uderzali Go jedni w policzek, inni w kark, mówiąc: „Prorokuj nam, kto Cię uderzył!”

\section{Conformatio}

Tak niech każdy brat, współcierpiąc z Chrystusem, wspomina wyśmiewanie i zniewagę, którą Pan wtedy wycierpiał oraz to, jak Żydzi żartowali z Niego jak z chłopca. Nie wystawiajmy Go na próbę, oczekując proroctwa albo dowodu, także duchowo w tym, co jest sprawą wiary. Niech brat nie dopuszcza do tego, co jako grzechy przemilczał już Chrystus, mając jakby zasłoniętą twarz, ponieważ kiedy nastąpi sąd, Jego ręka wymierzy wrogom zemstę. I każdy brat powinien znieść wszystkie ziemskie kary, zanim znieważy oczy Chrystusa sędziego. Dlatego niech brat usilnie błaga Chrystusa, bojąc się Jego strasznego widoku, który teraz jest zakryty, lecz ma być odsłonięty w czasie sądu, i mówi: „Uczyń mi, Panie, teraz według Twego upodobania! Nałóż prawa, dodaj udręczeń, pomnóż przeciwności, ustokrotnij słabości, cokolwiek Ci się podoba zniosę z wielką chęcią, prosząc tylko o to, abyś raczył zachować mnie od oblicza Twojej zapalczywości!” Teraz wyjdźmy razem $\mathrm{z}$ naszym Panem $\mathrm{z}$ niesprawiedliwego domu kapłana Kajfasza.

15

\section{Passio}

Potem, rano, około godziny pierwszej tłum Żydów zaprowadził Pana Jezusa z domu Kajfasza do pretorium i związanego okazano Go namiestnikowi Poncjuszowi Piłatowi. 


\section{Conformatio}

Sic frater quilibet recogitet, quomodo secundum Apostolum 'oportet nos omnes exhiberi ante tribunal Christi ${ }^{\text {LXII }}$ et idcirco ipse pro nobis impiis exhiberi uoluit, ut nos ante tribunal iusti iudicis fiducialius compararemus. Christus etiam Deus et homo ante hominem Pilatum stabat et irreuerentie uerbum non est locutus. Sic et nos cum reuerentia stare debemus coram prelatis nostris, ipsi enim tenent locum Dei. Nam omnis potestas est a Deo ${ }^{\text {LXIII }}$ ut dicit Apostolus ad Romanos XIII. Hinc Dominus [ $\mathrm{W}^{2}$ f. 63r] ait ad Pilatum 'Non haberes potestatem in me nisi tibi data est desuper' ${ }^{\text {LXIV }}$. Ibi dicit glosa 'Cupiditatem nocendi mali prelati habere possint a seipsis, sed potestatem non habent nisi a Deo' ${ }^{\text {LXV }}$. Potestas autem datur a Deo malis, ut bonorum patientia probetur et malorum iniquitas puniatur. Sic per potestatem Pilato datam a Deo occisus est Christus, ut totum genus humanum redimeret.

16

\section{Passio}

Postquam Iesus Christus uinctus stetisset in pretorio coram Pilato et Iudei starent foras, ne contaminarentur, exiuit ad eos Pilatus dicens 'Quam accusationem fertis aduersus hominem hunc? ${ }^{\text {LXVI }}$ Et Iudei responderunt Iesum esse malefactorem.

\section{Conformatio}

Sic fratres caueatis, ne accusare possitis de malo facto, quoniam illius Deus iudex est retribuens unicuique iuxta opera sua nec mala uestra imponatis aliis uos excusando, quemadmodum Eua imposuit peccatum suum dyabolo et Adam Eue. Quia ut dicit glosa su-

\section{Conformatio}

Tak niech każdy brat przypomni sobie, jak według apostołów: „My wszyscy bowiem musimy się ukazać przed stolicą Chrystusową" i dlatego sam za nas niegodziwych chciał być pokazany, abyśmy z większą ufnością przygotowali się na sąd sprawiedliwego sędziego. Także Chrystus Bóg i człowiek stał przed człowiekiem Piłatem i nie wyrzekł słowa zniewagi. Tak i my powinniśmy stać z szacunkiem wobec naszych przełożonych, zajmują oni bowiem miejsce Boga. Albowiem „każda władza pochodzi od Boga”, jak mówi Apostoł do Rzymian, XIII. Dlatego Pan powiedział do Piłata: „Nie miałbyś żadnej władzy nade mną, gdyby ci z góry nie była dana”. Glosa do tego miejsca: „Źli przełożeni mogą posiadać własną żądzę szkodzenia, ale władzę mają tylko od Boga”. Władza zaś dawana jest przez Boga złym, aby cierpliwość dobrych była wystawiona na próbę, a niegodziwość złych ukarana. Tak przez władzę daną przez Boga Piłatowi umarł Chrystus, aby odkupić cały rodzaj ludzki.

\section{6}

\section{Passio}

Po tym, jak Jezus Chrystus związany stanął przed Piłatem, a Żydzi stali na zewnątrz, aby się nie skalać, wyszedł do nich Piłat, mówiąc: „Co za skargę przynosicie przeciw temu człowiekowi?", a Żydzi odpowiedzieli, że Jezus jest złoczyńcą.

\section{Conformatio}

Tak, bracia, strzeżcie się, abyście nie oskarżali o zły czyn, ponieważ od tego Bóg jest sędzią, oddającym każdemu według jego uczynków. Usprawiedliwiając się zaś, nie obarczajcie innych swoimi niegodziwościami, tak jak Ewa obarczyła swoim grzechem szatana, a Adam 
per illud Psalmo 'Nolite extollere in altum cornu uestrum'LXVII ' 'Maximum est uitium excusatio peccati' ${ }^{\text {LXVIII }}$ id est 'est quedam circumstantia aggrauans peccatum et tanto dicitur esse maximum peccatum, quia quodlibet facit magis' ${ }^{\text {LXIX }}$ ut dicit Thomas, Secunda Secunde questio 14 articulo 2. Habent enim consuetudinem aliqui, ut etiam peccata sua retorquent in deum et stellas, quod reprehendit Augustinus [ $\mathrm{W}^{1}$ f. 133r] super Psalmum XXXI dicens 'Verum est quod Deus fecit et te et stellas et hec omnia bona, sed hoc quod Deus creauit non te cogit ad peccandum, sed malitia uoluntatis tue ${ }^{\text {LXXI. }}$.

\section{7}

\section{Passio}

Dominus Iesus postquam falsas accusationes sustinuisset coram Pilato, missus est ab eo ad Herodem. Et hec missio bene computatur inter articulos passionis Domini, quia penale est mitti de uno iudice ad alium.

\section{Conformatio}

Sic fratres nolite turbari, si mittemini interdum ex obedientia de loco ad locum. Dixi ex obedientia, quia alias religiosi discurrere non debent, quia 'Fons et origo omnium malorum sunt inutiles discursus religiosorum sicut e contrario fons et origo omnium bonorum spirituali homini est in cella sua iugiter commorari ${ }^{\text {LXXII }}$ ut angelus reuelauit Fratri Amando ut patet in Horalogio libro II rubrica III. Qui uult ergo perfectionem spiritualis uite attingere, debet seipsum abstrahere a societatibus nociuis et ab omnibus hominibus religionem impedientibus. Nam puritas mentis, que maxime religiosis est necessaria, conseruatur, si sensus exteriores
Ewę. Ponieważ, jak mówi glosa do psalmu: „nie podnoście ku górze rogu waszego” - „Największym błędem jest usprawiedliwianie grzechu”, to znaczy, że „jest jakąś okolicznością obciążającą grzech i o tyle można go uważać za największy grzech, że każdy grzech czyni większym”'LXX, jak mówi Tomasz w Secunda Secundae w kwestii $14, w$ artykule 2 . Niektórzy mają bowiem zwyczaj, żeby także swoje grzechy zrzucać na Boga i gwiazdy, co gani Augustyn w Super Psalmum XXXI, mówiąc: „Prawdą jest, że Bóg uczynił i ciebie, i gwiazdy, i te wszystkie dobra, lecz nie to, co Bóg stworzył, zmusza cię do grzechu, lecz twoja zła wola”.

\section{7}

\section{Passio}

Po tym, jak Pan Jezus zniósł fałszywe oskarżenia $\mathrm{w}$ obecności Piłata, został przez niego wysłany do Heroda. I to wysłanie słusznie zaliczone jest do części Męki Pańskiej, ponieważ wysyłanie przez jednego sędziego do innego zasługuje na karę.

\section{Conformatio}

Tak, bracia, nie niepokójcie się, jeśli czasem z mocy posłuszeństwa będziecie wysyłani z jednego miejsca $w$ inne. Powiedziałem „z mocy posłuszeństwa”, ponieważ inaczej zakonnicy nie powinni się przemieszczać, gdyż „źródłem i początkiem wszelkiego zła jest niepotrzebne przemieszczanie się zakonników” i przeciwnie „źródłem i początkiem wszelkiego dobra dla osoby duchownej jest przebywanie w celi", jak anioł objawił Fratri Amando w Horologium w księdze 2, rozdziale 3. Kto więc chce osiągnąć doskonałość życia duchowego, powinien oderwać się od szkodliwego towarzystwa i od wszystkich ludzi wrogich religii. Albowiem czystość ducha, 
uel interiores prohibeantur, ne uagentur circa carnalia et terrena. Sed si homo ad seipsum conuertatur et in seipso maneat, absoluens affectum ab omni re, que potest alligare et retinere ipsum iuxta illud legis Mosaice 'Maneat unusquisque apud semetipsum. Nullus egrediatur hostium domus sue die sabbati ${ }^{\text {LXXIII }}$. Religiosus tunc sabbatisat et maneat in seipso, quando dispersiones cordis sui et affectiones ad unum uerum et simplicissimum bonum recolligit. Et siue comedat siue bibat siue aliquid aliud faciat siue etiam de loco ad locum moueatur, semper hec uox resonet ${ }^{\mathrm{LXXIV}}$ in auribus eius admonentis et dicentis 'Fili mi ad cor redias quantum [ $\mathrm{W}^{2}$ f. $63 \mathrm{v}$ ] possibile est teipsum abstrahendo!. Hanc salubrem doctrinam Arsenius breuibus uerbis conclusit et discipulis seruare mandat dicens 'Fuge, tace et quiesce. Hec enim' ut ipse inquit 'sunt principia salutis' ${ }^{\mathrm{LXXV}}$.

18

\section{Passio}

Postquam Dominus Iesus presentatus fuit Herode, interrogauit eum multis sermonibus scilicet derisorie se habens ad ipsum et eum subsanans, sed Christus nichil respondit.

\section{Conformatio}

Sic fratres uerba uestra non effundatis, ubi non est spes emendationis et nolite frangi iniuriis. Nam quotienscumque, qui uos impugnant seu criminantur et aduersa inferunt, uoluntarie cesseritis et eorum, qui ${ }^{\mathrm{LXXVI}}$ uerbis importune inuadunt, iram et impatientiam tam mansuete et cum cordis dulcedine et uerborum suauitate ac uultus hilaritate $\left[\mathrm{W}^{1}\right.$ f. $\left.133 \mathrm{v}\right]$ reciperitis, która jest najbardziej potrzebna zakonnikom, zostaje zachowana, jeśli odczucia zewnętrzne i wewnętrzne są powstrzymywane przed błąkaniem się między sprawami cielesnymi i ziemskimi. Lecz jeśli człowiek nawróci się na samego siebie i będzie trwał w samym sobie, uwolni swoje uczucia od każdej rzeczy, która może go związać albo zatrzymać, zgodnie z prawem Mojżesza: „Każdy niech zostaje u siebie, niech nikt nie wychodzi z domu swego dnia siódmego". Zakonnik wtedy świętuje i trwa w samym sobie, kiedy rozproszenia swojego serca i uczucia zbierze do jednego, prawdziwego, najprostszego dobra. I czy spożywa, czy pije, czy coś innego czyni, czy jest przenoszony z miejsca na miejsce, niech zawsze w jego uszach brzmi głos napominającego i mówiącego: „Mój synu wróć do serca, o ile możliwe jest oderwanie się od siebie”. Tę pożyteczną naukę Arseniusz zawarł w krótkich słowach i polecił uczniom zachować, mówiąc: „uciekaj, milcz i bądź spokojny, to są bowiem”, jak on sam mówi, „zasady zbawienia”.

18

\section{Passio}

Po tym, jak Pan Jezus został okazany Herodowi, ten wypytał Go w wielu słowach, mianowicie szydząc i wyśmiewając Go, lecz Chrystus nic nie odpowiedział.

\section{Conformatio}

Tak, bracia, nie trwońcie waszych słów tam, gdzie nie ma nadziei na poprawę i nie ulegajcie niesprawiedliwości. Albowiem za każdym razem, gdy tym, którzy was prześladują lub oskarżają i sprowadzają przeciwności, dobrowolnie ustąpicie i gniew oraz niecierpliwość tych, którzy dokuczliwie atakują słowami, tak spokojnie, z łagodnością serca, ze słody- 
ut uestra dulcis benignitas aduersariis uerecundiam inferre possit et eorum tumor ex uestra humilitate confringatur, tunc mortis Christi ymago et similitudo in uobis ueraciter relucebit. Et sicut uos fecistis socios magne tribulationis, eritis et socii magne consolationis, quia hoc sensistis in uobis, quod in Christo Iesu sentiebatis.

19

\section{Passio}

Postquam Dominus Iesus stetit coram Herode, accusabatur a principibus sacerdotum et scribis, quod commouisset uniuersum populum incipiendo a Galilea. Et Christus tacuit.

\section{Conformatio}

Sic fratres non omni loco et tempore coram quolibet ueritas est manifestanda, sed plerumque obticenda coram indignis et derisoribus. Nam ueritas et doctrina est pro custodia animarum a Deo per angelos ordinata, que non accipitur ab aliquo, qui principia doctrine prius apud se non habuerit ut sunt infideles et indigni. Vnde Paulus et Barnabas dixerunt Iudeis contradicentibus et blasphemantibus uerbum Domini 'Vobis oportebat primum loqui uerbum Dei, sed quoniam repulsistis illud et indignos uos iudicatis eterne uite, ecce conuertimur ad gentes ${ }^{\text {LXXVII }}$, ut habetur in Actibus Apostolorum. Sic fratres uideatis, ne uos cum Iudeis faciatis indignos uerbo Dei, quod pro salute uestra uariis modis uobis communicatur. czą słów i z radością na twarzy przyjmiecie, aby wasza słodka życzliwość mogła wywołać szacunek u wrogów, a ich wzburzenie zostało poskromione waszą pokorą, wtedy obraz umarłego Chrystusa i podobieństwo do Niego prawdziwie w was zajaśnieje. I tak jak uczyniliście się towarzyszami w wielkim udręczeniu, tak będziecie także towarzyszami w wielkim pocieszeniu, ponieważ w sobie odczuliście to, co czuliście w Jezusie Chrystusie.

19

\section{Passio}

Po tym, jak Pan Jezus stanął przed Herodem, najważniejsi spośród kapłanów i pisarzy oskarżali Go, że podburzał cały lud, zaczynając od Galilei. A Chrystus milczał.

\section{Conformatio}

Tak, bracia, nie w każdym miejscu i czasie wobec każdego powinna być ujawniana prawda, lecz należy ją przemilczeć zwłaszcza wobec niegodziwych i szyderców. Albowiem prawda i nauka zostały przekazane przez aniołów od Boga dla ochrony dusz i nie powinny być przyjmowane przez kogoś, kto wcześniej nie pojął zasad nauki, jak niewierni i niegodziwi. Dlatego Paweł i Barnaba powiedzieli do Żydów sprzeciwiających się i bluźniących Słowu Bożemu: „Wam trzeba było najpierw opowiadać słowo Boże; ale ponieważ je odrzucacie, i osądzacie się sami za niegodnych wiecznego życia, oto zwracamy się do pogan”, jak mówią Dzieje Apostolskie. Tak bracia baczcie, abyście razem z Żydami nie czynili rzeczy niestosownych wobec Słowa Bożego, co dla waszego zbawienia na różne sposoby jest wam przekazywane. 


\section{Passio}

Postquam Dominus Iesus nullum signum fecisset coram Herode nec respondisset accusantibus se defendendo responsionibus, eum Herodes fatuum et insani mentis reputabat et spreuit cum exercitu suo, quod ad passionem pertinet, quia quilibet dolet quando uidet se ab aliis suspectum.

\section{Conformatio}

Sic fratres nolite conformes ${ }^{\text {LXXVIII }}$ esse Herodi et suis et simplices et humiles despiciendo, nam tales etsi sint in occulis hominum abiecti, tamen sunt in occulis Domini ualde accepti. Vnde dicitur in Libro Sapientie 'Iustorum anime in manu Dei sunt ${ }^{\text {LXXIX }}$. Et sequitur 'Visi sunt occulis insipientium mori; illi autem sunt in pace ${ }^{\mathrm{LXXX}}$. Et similiter uos debetis cum Christo potius uelle despici ab aliis quam $\mathrm{ab}$ adolatoribus laudari uelle. Et hoc est quod propheta a Domino petiit dicens 'Corripiat me iustus in misericordia et increpabit me: oleum autem peccatoris non inpinguet caput meum ${ }^{\text {'LXXI }}$. Glosa 'Oleum peccatoris est falsa laus adolatoris et simulata dilectio, que mentes a rigore ueritatis emollit ad noxium ${ }^{\text {LXXXII. }}$ [W2 f. 64r]

\section{Passio}

Dominus Iesus postquam despiciebatur ab Herode, eductus est ueste alba ab ipso in derisionem et contempnum.

\section{Conformatio [ $\mathrm{W}^{1}$ f. 134r]}

Sic frater quilibet regratiatur Christo, quod sibi uestem albam baptismalis innocentie conferre dignatus est et gemat, quod sepius eam cum peccatorum maculis denigrauit. Quamquam

\section{Passio}

Po tym, jak Pan Jezus nie uczynił żadnego znaku wobec Heroda, ani broniąc się nie odpowiedział na oskarżenia, Herod uznał Go za głupiego i chorego na umyśle i wraz ze swoim wojskiem wyszydził Go, co jest częścią Męki, ponieważ każdy cierpi, gdy spostrzega, że jest podejrzewany przez innych.

\section{Conformatio}

Tak, bracia, nie naśladujcie Heroda i jego [sług], gardząc głupimi i prostymi, ponieważ tacy, chociaż w oczach ludzi odrzuceni, jednak w oczach Pana są bardzo pożądani. Dlatego mówi się w Księdze Mądrości: „Dusze sprawiedliwych są w ręce Bożej” i dalej: „Zdało się oczom głupich, że umarli, lecz oni są w pokoju”. I wy podobnie powinniście raczej razem z Chrystusem chcieć być wzgardzeni przez innych, niż chwaleni przez pochlebców. I tego prorok żądał od Pana, mówiąc: „Będzie mię karcił sprawiedliwy w dobroci i będzie mię łajał; lecz olejek złośnika niechaj nie namaszcza głowy mojej”, glosa: „Olejek występnego to fałszywa pochwała pochlebcy i udawana miłość, która osłabia umysły, [prowadząc je] od surowej prawdy do rzeczy szkodliwych".

\section{1}

\section{Passio}

Po tym, jak Jezus Chrystus został wzgardzony przez Heroda, wyprowadzono Go w białej szacie dla wzbudzenia drwin i pogardy.

\section{Conformatio}

Tak niech każdy brat dziękuje Chrystusowi, że raczył mu powierzyć na chrzcie białą szatę niewinności i niech żałuje, że wielokrotnie brudził ją plamami grzechów. Chociaż bowiem 
enim uestis alba ${ }^{\text {LXXXIII }}$ in Christo fuit exprobrabilis, facta est postea ualde honorabilis, ut quilibet per baptismum renatus induitur ueste alba in signum innocentie, quam confert baptismus. Non ergo turbari debetis fratres, si pro candore uite illudemini ab hominibus uanis, sed potius gaudeatis, quia Christus pro uobis in alba ueste illusus est, que etiam seruit alba sacerdotalis. Nolite etiam fratres querere in uestibus ornatum seu preciositatem, sed solum necessitatem, quia saluator noster in ueste uelut fatuus illusus est.

\section{2}

\section{Passio}

Postquam Dominus Iesus spretus fuisset ab Herode, cum non inuenisset in eo causam mortis, alba indutum remisit ad Pilatum. Et sic, qui prius fuerunt inimici, facti sunt amici.

\section{Conformatio}

Sic frater quilibet, si habeat inimicitiam cum aliquo, dimittat ei ex misericordia et amore Christi, qui pro nobis in sua passione malos et inimicos concordabat. Nam ut dicit Crisostomus super Mattheum exhortatione LXI ostendens qualiter inimicitia et rancor ${ }^{\text {LXXXIV }}$ ledat cor proprium inquiens 'Numquam tibi tantum dolorem alius inferre poterit, quam cum ipse tibi, si recordatus ire uindictam queris et aduersus teipsum sententiam iudicis attrahis ${ }^{\mathrm{LXXXV}}$. Qui autem iniurias, unde causantur inimicitie, libenter dimittit in quantum plures dimittit tantum meretur accipere peccatorum suorum dimissionem. Et sic qui iniurias infert beneficium tribuit patienter sufferenti. Nam ut dicit Crisostomus ibidem 'Si uoluerimus, nemo nobis unquam iniuriari poterit, sed cum inimici biała szata była u Chrystusa powodem hańby, stała się później bardzo zaszczytna, aby każdy odrodzony przez chrzest wdziewał białą szatę na znak niewinności, którą daje chrzest. Nie powinniście więc, bracia, niepokoić się, jeżeli za piękno życia będziecie wyśmiewani przez próżnych ludzi, lecz raczej się cieszcie, ponieważ Chrystus za was został wyszydzony w białej szacie, która również służyła jako alba kapłańska. Nie szukajcie także w szatach ozdoby ani kosztowności, lecz tylko konieczności, gdyż nasz Zbawiciel został wyśmiany w szacie jak głupiec.

22

\section{Passio}

Po tym, jak Herod wyszydził Pana Jezusa, ponieważ nie znalazł w Nim powodu kary śmierci, odzianego w białą szatę odesłał do Piłata. I tak ci, którzy wcześniej byli wrogami, stali się przyjaciółmi.

\section{Conformatio}

I tak każdy brat, jeśli byłby z kimś w nieprzyjaźni, niech mu wybaczy z miłosierdzia i miłości Chrystusa, który dla nas swoją Męką pojednał złych i dobrych. Albowiem jak mówi Chryzostom w Super Matthaeum, Exhortatio LXI, pokazując jak nieprzyjaźń i nienawiść rani własne serce, mówiąc: „Nigdy nikt nie będzie mógł zadać ci tak wielkiego bólu, jak czynisz to samemu sobie, kiedy wspominając gniew szukasz zemsty i zwracasz przeciwko sobie orzeczenie sędziego". Kto zaś krzywdy, które powodują nieprzyjaźnie, chętnie wybacza, o ile liczne wybacza, o tyle zasługuje na przyjęcie przebaczenia swoich grzechów. I tak, kto wyrządza krzywdy, czyni dobrodziejstwo wytrwale cierpiącemu. Albowiem, jak mówi Chryzostom tamże: „Gdybyśmy chcieli, nikt nigdy nie mógłby nas krzywdzić, 
sint precipua tamen nobis conferunt lucra. Quis enim maior inimicus est hominis quam dyabolus? Tamen occasionem affert corone sustinentibus ut in beato Iob manifestum est ${ }^{\text {LXXXVI }}$. Et qui oppressiones inimicorum equo animo suffert, iocunditatem animi consequitur nec uitam uanis laboribus ac doloribus unquam consumet, nam ${ }^{\text {LXXXVII }}$ qui nescit odisse nec tristari cognouit $^{\text {LXXXVIII }}$ ut ait Crisostomus ut supra.

\section{3}

\section{Passio}

Postquam Dominus Iesus adductus esset ad Pilatum de Herode et non inuenisset in eo causam mortis, uoluit eum dimittere ad solemnitatem Pasche, sed Iudei contradixerunt petentes ${ }^{\text {LXXXIX }}$ sibi dimitti Barraban, qui erat homo sediciosus, homicida et latro, propter quod fuit uinculatus in carcerem. [W ${ }^{1}$ f. 134v]

\section{Conformatio}

Sic fratres karissimi equo animo tollerare debetis si quando preualentur uobis persone infirmiores et humiliores, quia Christo prelatus fuit latro. Et caueatis, ne et uos Barraban Christo preferetis. Quandocumque enim mala agitis, solutus est in corpore uestro Barrabas et e contrario quando bene agitis solutis Christum, Barraban uero ligatis in signum huius. Postquam Iudei elegerunt Barraban, fecerunt eius opera scilicet latrocinia et seditiones intantum quod potentiam et regnum suum perdiderunt. Qui autem Christum eligunt et sequuntur eius opera, acquirunt uitam eternam omni amenitate plenam. [W' f. 64v] Quia ipse ait 'Vbi ego sum, illic erit et minister meus'. Ex quo Christus uult uos secum esse. Quis uestrum non cupit et uehementer desiderat dissolui et esse cum lecz chociaż są nieprzyjaciółmi, przynoszą nam jednak nadzwyczajne korzyści. Któż bowiem jest większym nieprzyjacielem człowieka niż diabeł? A jednak cierpiącym daje sposobność zyskania korony, co widać u błogosławionego Hioba”. I kto znosi z rozwagą niegodziwości nieprzyjaciół, zyskuje radość ducha i nigdy nie zmarnuje życia próżnymi trudami i zmartwieniami, ponieważ „kto nie umie nienawidzić, nie zna smutku”, jak mówi Chryzostom, jak wyżej.

\section{3}

\section{Passio}

Po tym, jak Pan Jezus został przyprowadzony od Heroda do Piłata, a ten nie znalazł w Nim powodu kary śmierci, zechciał, aby uwolniono Go [Chrystusa] na święto Paschy, lecz Żydzi sprzeciwili się, żądając, aby wypuścił Barabasza, który był buntownikiem, mordercą i łotrem, za co przetrzymywano go $\mathrm{w}$ więzieniu.

\section{Conformatio}

Tak, bracia najdrożsi, ze spokojem ducha powinniście cierpieć, jeśli kiedyś osoby mniej znaczące i gorszego pochodzenia będą miały przed wami pierwszeństwo, ponieważ nad Chrystusa został wyniesiony łotr. I strzeżcie się, abyście i wy nie przedkładali Barabasza nad Chrystusa. Kiedykolwiek bowiem czynicie zło, w waszym ciele uwalniany jest Barabasz, i przeciwnie, kiedy czynicie dobro, uwalniacie Chrystusa. Barabasza zaś przywiązujecie do jego znaku. Po tym, jak Żydzi wybrali Barabasza, czynili jego dzieła, czyli rozboje i zamieszki, do tego stopnia, że stracili swoje wpływy i władzę. Ci zaś, którzy wybierają Chrystusa i podążają za Jego dziełami, zyskują życie wieczne pełne wszelkiej rozkoszy. Ponieważ On sam mówi: „gdzie Ja jestem, tam i sługa mój będzie”. Dlatego Chrystus chce, że- 
eo, transire de statu miserie de loco pugne in libertatem glorie filiorum Dei? Dicat quisquam 'Tempus est Domine. Sufficit michi. Tolle animam meam. Neque enim melius sum quam patres mei'.

24

\section{Passio}

Dominus Iesus quando non potuit dimitti a Pilato propter clamorem Iudeorum, apprehendit eum Pilatus et iussit eum exui uestibus quibus erat indutus.

\section{Conformatio}

Sic fratres quandocumque mundana solacia fugitis et utilitates et consolationes terrenas propter Christum relinquitis nisi quantum necessitas hec requirit et quando uos spoliatis uoluntate propria, tunc cum Christo nudi statis exuti propriis uestimentis. Corporaliter uero nudi apparere non debetis nam primi parentes se nudos uidentes erubuerunt a facie Dei. Est etiam nuditas conuersationis bone et hanc uirtutibus cooperire debemus de qua dicitur Apocalipsa III 'Vestibus albis induaris, ne appareat confusio nuditatis tue ${ }^{\mathrm{XC}}$. Conuersatio nostra ${ }^{\mathrm{XCI}}$ debet sic esse ornata seu uestita, ut etiam minimis careat peccatis. Nam per illorum incuria gradatim semper ascenditur ad maiora. Nam ut ait Crisostomus super Mattheum exhortatione XXXVI 'Non uim delicti solam consideres nec quia paruum sit delictum, sed illud precipue tene, quod $^{\mathrm{XCII}}$ $\mathrm{si}^{\mathrm{XCIII}}$ radicem non euelleris, magna inde arbor succrescet $^{\text {XCIV }}$. Vnde cito ex paruis maxima fiunt. Noli ergo dicere 'Quid est, si hoc fecero, tamen paruum est'. Nam ibidem narrat Crisostomus 'Quidam importune risit reprehen- byśmy byli z Nim. Któż z was nie pożąda i nie pragnie usilnie uwolnić się i być z Nim, przejść ze stanu nieszczęścia, z miejsca walki, do wolności chwały synów Boga. Niech każdy powie: „Już czas Panie. Wystarczy. Przyjmij moją duszę. Nie jestem bowiem lepszy niż moi ojcowie”.

\section{4}

\section{Passio}

Gdy Pan Jezus nie mógł zostać uwolniony przez Piłata z powodu krzyku Żydów, pochwycił Go Piłat i rozkazał odrzeć z szat, w które [Chrystus] był odziany.

\section{Conformatio}

Tak, bracia, ilekroć unikacie doczesnych nagród i pozostawiacie korzyści i porzucacie pociechy ziemskie z powodu Chrystusa, oprócz sytuacji, w której wymaga tego konieczność i kiedy z własnej woli odzieracie się z odzienia, wtedy stoicie z Chrystusem nadzy, pozbawieni własnych szat. Fizycznie nadzy nie powinniście się pokazywać, ponieważ pierwsi rodzice widząc, że są nadzy, zawstydzili się na widok Boga. Istnieje także nagość dobrej rozmowy i właśnie ją powinniśmy przyodziać cnotami, o której mówi Apokalipsa 3: „żebyś się ubrał w szaty białe, żeby się nie okazywała sromota nagości twojej”. Nasza rozmowa powinna być tak przozdobiona lub odziana, żeby być wolna od najmniejszych grzechów. Albowiem przez ich zaniedbanie zawsze stopniowo zmierza się ku większym [grzechom]. Albowiem jak mówi Chryzostom w Super Matthaeum, Exhortatio XXVI: „Nie oceniaj wagi występku, ani czy jest on mały, lecz o tym przede wszystkim pamiętaj, że jeśli nie wyrwiesz korzenia, wyrośnie z niego wielkie drzewo". Dlatego szybko z małych powstają największe. Nie mów więc: „Cóż się stanie, jeśli to uczynię, prze- 
sus a quopiam est respondit ille nichil esse id mali nec ipse aliquid mali sequi posse. Orta tamen est ex immoderato risu paulisper scurrilitas, a scurrilitate tourpiloquium, a tourpi[W ${ }^{1}$ f. 135r] loquio operatio turpis' ${ }^{\mathrm{XCV}}$.

\section{5}

\section{Passio}

Postquam Dominus Iesus nudatus esset coram Pilato, tunc apprehendit eum et flagellauit.

\section{Conformatio}

Sic frater quilibet poterit seipsum flagello uel uirga corporali cedere si habet gratiam uel saltem conpatiendo Christo flagellato mentaliter se flagellaret, ut dicere possit cum Psalmista 'Quoniam ego in flagella paratus sum'XCVI ${ }^{\text {. Re- }}$ cogitet etiam frater quilibet, quod uulnera tunc Dominus noster recepit pro peccatis nostris. Peccata enim merentur flagella. Et quia peccata nostra sunt innumerabilia, ideo plage $\mathrm{XCVII}$ Christi erant innumerabiles. Hinc dicitur Ysaie 'A planta pedis usque ad uerticem non est in eo sanitas' ${ }^{\text {XCVIII }}$. Et quamquam plage in hac flagellatione sibi inflicte ex certitudine sciri non possent humanitus, possent tamen sciri per reuelationem. Vnde Bernhardus dicit, quod uulnera, que Christus pro nobis pertulit et passus est in toto corpore sint quinque milia ducenta et LX, uersus: L super X duo CC superaddita milia quinque. Tot fertur Christus pro nobis uulnera passus ${ }^{\mathrm{XCIX}}$. Et si quilibet uestrum uoluerit reddere uulneribus ${ }^{\mathrm{C}}$ Christi debitas gratias, dicat omni die cum deuotione XV Pater Noster per integrum annum, tunc cuilibet uulneri tamen unum Pater Noster dixistis. Voluite ergo fratres et reuoluite huc cież to mały [grzech]”. Albowiem Chryzostom przedstawia tamże: „ktoś zaśmiał się nie w porę, został zganiony przez innego, odpowiedział tamten, że to nic złego i nic złego za sobą nie pociąga. Wnet powstało jednak z nieumiarkowanego śmiechu błazeństwo, z błazeństwa rozwiązłość w mowie, a z niej haniebne postępowanie”.

\section{5}

\section{Passio}

Po tym, jak Pan Jezus został obnażony wobec Piłata, ten pochwycił Go i ubiczował.

\section{Conformatio}

Tak każdy brat będzie mógł bić siebie samego biczem lub prawdziwą rózgą, jeśli posiądzie łaskę, lub przynajmniej biczować się w duchu, współczując biczowanemu Chrystusowi, aby móc powiedzieć z psalmistą: „Bo ja na bicze gotów jestem”. Niech również każdy brat przypomni sobie, że Pan przyjął wówczas rany za nasze grzechy. Grzechy bowiem zasługują na biczowanie. A ponieważ nasze grzechy są niezliczone, razy Chrystusa były niezliczone. Dlatego jest powiedziane w Księdze Izajasza: „Od stopy nogi aż do wierzchu głowy nie ma w Nim zdrowia”. I chociaż razów wymierzonych sobie w tym biczowaniu nie można w sposób pewny rozumieć po ludzku, można jednak zrozumieć je przez objawienie. Dlatego Bernard mówi, że ran, które Chrystus za nas zniósł i wycierpiał na całym ciele, jest pięć tysięcy dwieście sześćdziesiąt; werset: „50 więcej 10 [i] dwa [razy po] 100 dodane do pięciu tysięcy". Tyle zniósł Chrystus za nas ran, cierpiąc. I jeśli ktoś z was chciałby oddać ranom Chrystusa należne dziękczynienie, niech pobożnie odmawia każdego dnia piętnaście Ojcze nasz przez cały rok, wtedy dla każdej rany jeden Ojcze nasz odmó- 
et illuc dominicum corpus ubique inuenietis dolorem ubique cruorem.

\section{6}

\section{Passio}

Postquam Dominus Iesus flagellatus fuit ligatus in columpna, milites id est ministri Pilati, qui erant gentiles, illudendo ei induebant eum ueste porpurea.

\section{Conformatio $\left[\mathrm{W}^{2}\right.$ f. 65r]}

Sic fratres si aliquando illudemini uestibus religiosis a stultis hominibus, nolite uos defensare, sed ad memoriam reducite quod Christus in ueste seu in clamide coccinea seu purpurea illusus fuit. Et sicut Christus cruentata uulnera operire uoluit ueste coccinea, sic uos opera uestra cruenta id est peccata operire debetis ueste caritatis. Caritas enim operit et multitudinem peccatorum inquantum constituit amicitia inter Deum et peccatorem penitentem. Amicus autem obliuiscitur omnium iniuriarum amici alias non possint delectabiliter sibi mutuo conuiuere quod tamen proprium est amicorum ${ }^{\mathrm{CI}}$ ut dicit Aristoteles.

\section{7}

\section{Passio [ $W^{1}$ f. 135v]}

Postquam Dominus Iesus indutus fuit ueste regali, ministri plectebant coronam de spinis et imposuerunt capiti eius delusorie pro dyademate regali et intantum infixe fuerunt capiti eius, quod usque ad cerebrum pertingerent. Hinc sanguis frontem, genas et collum perfudit.

\section{Conformatio}

Sic fratres coronetis uos spinea corona id est uita arta abstinentiarum et puritate conscientie. Hec enim sunt quedam spine propter auste- wicie. Rozważajcie, bracia, na różne sposoby w tę i w tamtą stronę ciało Pańskie, wszędzie odnajdziecie ból, wszędzie krew.

\section{6}

\section{Passio}

Po tym, jak Pan Jezus przywiązany do słupa został wychłostany, żołnierze, czyli słudzy Piłata, którzy byli poganami, szydząc z Niego, okryli Go purpurową szatą.

\section{Conformatio}

Tak bracia, jeśli kiedykolwiek będziecie wyszydzani przez głupich ludzi z powodu stroju duchownego, nie brońcie się, lecz przypomnijcie sobie, że Chrystus w szacie lub płaszczu szkarłatnym lub purpurowym został wyśmiany. I tak jak Chrystus chciał zakryć krwawiące rany szkarłatną szatą, wy wasze krwawe uczynki, czyli grzechy powinniście zakrywać szatą miłości. Miłość bowiem zasłania także wiele grzechów, o ile ustanowiła przyjaźń między Bogiem a pokutującym grzesznikiem. Przyjaciel zaś zapomina krzywd wyrządzonych przez nieprzyjaciela, inaczej nie mogliby dobrze ze sobą żyć, co jest cechą przyjaciół, jak mówi Arystoteles.

\section{7}

\section{Passio}

Po tym, jak Pan Jezus został odziany w królewską szatę, słudzy upletli koronę z cierni i szyderczo założyli Mu na głowę zamiast królewskiego diademu i tak bardzo [ciernie] wbiły się w Jego głowę, że doszły aż do mózgu. Dlatego krew polała się na twarz, policzki i szyję.

\section{Conformatio}

Tak, bracia, uwieńczcie się koroną cierniową, czyli trudnym życiem wyrzeczeń i czystością sumienia. To są bowiem jakby ciernie ze wzglę- 
ritatem, quam habent. Etiam fratres quotiens abicitis temptationes, que mentem uulnerare suis aculeis attemptant, totiens meremini coronari non corona spinea et difformi, sed potius corona aurea inserta lapidibus preciosis. Nam ille pro certo coronabitur, qui legittime certauerit temptationes superando. Temptabatur Eua de fructu prohibito, sed temptatione non restitit, sed eum apprehendit et comedit, ideo non coronam, sed maledictionem suscepit. Maria uero omnibus temptationibus dyaboli mundi et carnis penitus restitit, ideo coronatur in celis, ut merito regina celi dicatur.

28

\section{Passio}

Postquam Dominum Iesum coronabant, dederunt ei arundinem in dextera eius pro sceptro regali.

\section{Conformatio}

Sic fratres existimate uos infirmos et fragiles et omni bono uacuos nisi dextera Dei uos manu teneat. Hinc Psalmista ait 'Prouidebam Dominum in conspectu meo semper quoniam a dextris est michi non commouear' ${ }^{\text {CII }}$. Cogitationes enim uestre, quando fixe sunt in Domino, tunc Dominus conseruat uos dextera eius. Cogitationes autem rerum secularium trahunt ad labilitatem. Nam sicut ipse res labiles sunt, sic faciunt hominem, qui de ipsis cogitat, labilem. Cogitatio igitur bonorum in Deo immutabili est semper sine uagatione ad alia. Vnde anxiantur cum debent aliquid extra domum opus operari, unde non possunt in puncto hore eius contemplatione ${ }^{\mathrm{CIII}}$ carere $^{\mathrm{CIV}}$ ut dicit rabi Moyses de sancto Dauid super illud ubi dicit 'Prouidebam Dominum in conspectu meo semper etc. ${ }^{\text {CV }}$. du na surowość, którą mają. Również, bracia, ilekroć odrzucacie pokusy, które próbują ranić umysł swoimi kolcami, tylekroć zasługujecie na uwieńczenie nie koroną cierniową i brzydką, lecz raczej złotą koroną wysadzaną drogimi kamieniami. Albowiem ten na pewno zostanie ukoronowany, kto sprawiedliwie będzie walczył, pokonując pokusy. Ewa była kuszona zakazanym owocem, lecz nie sprzeciwiła się pokusie, wzięła go i zjadła, dlatego nie zyskała korony, lecz przekleństwo. Maryja zaś całkowicie oparła się wszystkim pokusom szatana, świata i ciała, dlatego jest koronowana w niebie, aby słusznie być nazywana królową nieba.

28

\section{Passio}

Po tym, jak ukoronowali Pana Jezusa, dali Mu do prawej ręki trzcinę zamiast królewskiego berła.

\section{Conformatio}

Tak, bracia, uważajcie się za nieudolnych i słabych, jeśli nie ochrania was prawica Boga. Dlatego psalmista mówi: „Miałem Pana zawsze przed oczyma swymi, bo mi jest po prawicy, abym nie był poruszony”. Kiedy bowiem wasze myśli są utwierdzone w Panu, wtedy strzeże was swoją prawicą. Myślenie o sprawach świeckich prowadzi do niestałości. Albowiem podobnie jak same rzeczy są niestałe, tak czynią niestałym człowieka, który o nich myśli. Zatem myślenie o rzeczach dobrych w niezmiennym Bogu jest zawsze wolne od zbaczania ku innym. Dlatego lękają się, kiedy muszą wykonać jakąś pracę poza domem, dlatego podczas Jego godziny nie mogą stronić od kontemplacji, jak mówi rabbi Mojżesz, gdy wspomina o świętym Dawidzie odnośnie do [słów]: „Miałem Pana zawsze przed oczyma swymi etc." 
29

\section{Passio}

Postquam milites id est communes serui Pilati Domino Iesu insignia regalia in ueste et sceptro adhibuissent, genu flexo adorabant eum illudendo dicentes 'Aue rex Iudeorum! ${ }^{\text {CVI }}$ quasi seipsum false regem fecisset.

\section{Conformatio}

Sic fratres nolite inepte cum ministris $\left[\mathrm{W}^{1}\right.$ f. 136r] seu stipendariis Pilati Christum adorare, sed adorate eum in spiritu et ueritate id est cum caritate et recta intentione, ut in adoratione Christi cor uestrum sit in uehementi desiderio sine tedio ad desiderandum celestia et si aliquando desideratis in oratione necessaria, tantum istud desiderare debetis propter habere celestia, ut ex corporalibus fiat processus $\left[\mathrm{W}^{2}\right.$ f. $\left.65 \mathrm{v}\right]$ ad spiritualia. Et sicut ministri adorabant Christum ut regem irrisorie, sic econtra nos debemus eum adorare ut regem uerum dicentes 'Aue crux' id est crucifixe, signatum pro signo 'spes unica'. Videatis etiam fratres, ne in adoratione uestra mens ab exteriori exhibitione discrepet. Nam ille pessime adoraret, qui ante altare genu flecteret et quomodo pallam, argentum uel ceram de ipso furaretur mente pertracteret. Nam tales essent Iude Scarioth similes, qui exterius exhibebat Christo amatoria et intus Deum tradere Iudeis disponebat.

30

\section{Passio}

Postquam satellites Pilati Dominum Iesum illusissent in genu flectendo et salutando, dabant ei alapas. Et sicut Dominus Noster alapam su-

\section{9}

\section{Passio}

Po tym, jak żołnierze, czyli zwykli słudzy Piłata, dali Panu Jezusowi insygnia królewskie w postaci szaty i berła, oddawali Mu cześć na klęczkach i szydząc, mówili: „Bądź pozdrowiony, Królu Żydowski!", jakby sam siebie fałszywie uczynił królem.

\section{Conformatio}

Tak, bracia, nie wielbijcie niestosownie Chrystusa razem ze sługami i najemnikami Piłata, lecz oddawajcie Mu cześć w duchu i prawdzie, to znaczy z miłością i prawdziwą troską, aby w uwielbieniu Chrystusa wasze serce bez zniechęcenia trwało $\mathrm{w}$ niepohamowanym pragnieniu spraw boskich. Jeśli kiedykolwiek prosicie w modlitwie o rzeczy konieczne, powinniście żądać tylko tego, co wiąże się ze sprawami boskimi, aby z tego, co doczesne, powstało dążenie do tego, co duchowe. Tak jak słudzy prześmiewczo wielbili Chrystusa jako króla, my, przeciwnie, powinniśmy oddawać $\mathrm{Mu}$ cześć jako prawdziwemu królowi, mówiąc: „Bądź pozdrowiony krzyżu”, czyli ukrzyżowany, znaczenie zamiast symbolu, „jedyna nadziejo”. Baczcie również, bracia, aby $\mathrm{w}$ trakcie adoracji wasz umysł nie różnił się od zewnętrznego wyglądu. Ten bowiem najgorzej oddaje cześć, kto klęczy przed ołtarzem i rozważa, jak ukraść $\mathrm{z}$ niego obrus, srebro lub wosk. Tacy są jak Judasz Iskariota, któty na zewnątrz pokazywał umiłowanie Chrystusa, a w duchu planował wydać Boga Żydom.

30

\section{Passio}

Po tym, jak słudzy Piłata wyszydzili Pana Jezusa, klękając i pozdrawiając Go, wymierzali $\mathrm{Mu}$ policzki. I jak Pan Nasz zniósł uderzenia 
stinuit in domo Anne a Iudeo, sic plures alapas sustinuit a ministris Pilati gentilibus in pretorio.

\section{Conformatio}

Sic fratres pro Christo non tantum unam iniuriam uobis illatam immo plures uel omnes pro Christo patienter sufferre debetis. Nam si plures iniurias sustineretis et unam ex indignatione animi et uindicta repelletis totum meritum patientie perderetis. Nam premium non datur principio operis uel medio, sed fini. Hinc saluator dicit 'Qui perseuerauerit usque in finem non tantum bona ${ }^{\mathrm{CVII}}$ faciendo, sed etiam mala sustinendo hic saluus erit ${ }^{\text {CVIII }}$. Ad bonum enim esse requiritur bonitas omnium operum, ad malum autem esse sufficit malitia unius operis sicut parua nigredo totum album pannum maculat et inficit et maculatum non uidebit regnum celorum.

31

\section{Passio}

Milites seu stipendarii pedestres postquam illusissent Dominum Iesum in alapis, conspuebant etiam in faciem eius. Ex quo patet, quod non fuerunt generosi, sed uiles stipendarii. Et sic Dominus Noster sputa recepit a Iudeis in domo Cayphe et similiter a gentilibus in pretorio Pilati.

\section{Conformatio}

Sic fratres uideatis, ne faciem Christi et alia sancta sputo peccatorum polluatis. Et quamquam $\left[\mathrm{W}^{1}\right.$ f. 136v] multa sint sancta, tamen in sacramento eukaristie est sanctus sanctorum, quia ibi certissime et ueraciter et absque omnium dubitatione continetur Deus et homo cum corpore, anima, carne et sanguine sicut fuit in utero matris et in cruce pependit et sedet ad dexteram patris. Caueatis ergo diligentissime, cum tam sanctissimum recipitis, ne sputum in eius fa- w domu Annasza od Żyda, tak liczne policzki od sług Piłata wytrzymał w pretorium.

\section{Conformatio}

Tak, bracia, powinniście cierpliwie znosić dla Chrystusa nie tylko jedną niegodziwość wam uczynioną, lecz wiele lub wszystkie. Albowiem jeśli wiele niegodziwości zniesiecie i jedną z niechęci duszy i zemsty odrzucicie, cały zysk $\mathrm{z}$ cierpliwości stracicie. Albowiem nagrody nie daje się na początku dzieła albo w środku, tylko na końcu. Dlatego Zbawiciel mówi: „kto wytrwa aż do końca, nie tylko czyniąc dobro, lecz także znosząc zło, ten będzie zbawiony”. Dobro wymaga, żeby wszystkie uczynki były dobre, złu zaś wystarczy jeden zły, tak jak trochę czerni plami i psuje całe białe płótno, również to, co splamione, nie ujrzy królestwa niebieskiego.

\section{1}

\section{Passio}

Żołnierze albo najemni piechurzy po tym, jak wyszydzili Pana Jezusa uderzeniami w policzek, opluli również Jego twarz. Z tego wynika, że nie byli zacnymi najemnikami, lecz pospolitymi. I tak Pan Nasz przyjął plwociny od Żydów w domu Kajfasza i podobnie od pogan w pretorium Piłata.

\section{Conformatio}

Tak, bracia, baczcie, abyście nie plamili śliną grzechów twarzy Chrystusa i innych świętości. I chociaż liczne są rzeczy święte, jednak w sakramencie Eucharystii jest Święty świętych, ponieważ tam najpewniej i prawdziwie i bez jakiegokolwiek zwątpienia przebywa Bóg i człowiek $\mathrm{z}$ ciałem, duszą, mięsem i krwią, jaki był w łonie matki, wisi na krzyżu i siedzi po prawicy Ojca. Strzeżcie się więc najpilniej, kiedy przyjmujecie Najświętszego, abyście nie pluli na Jego twarz. 
ciem mittatis. Mittit sputum in faciem Christi, qui in peccato mortali ipsum recipit. Nam sanctissimum in sanctis habitare desiderat. Hinc templa Deo sanctificantur, ut digne ibi inhabitet. Qui ergo templum Dei sanctum, quod estis uos, peccato mortali polluit et Christum in sacramento eukaristie sumit, presumptuosius facit quam Iudei et gentiles, qui faciem Christi corporalem sputis maculauerunt. Nam illi putabant irreuerentiam se facere puro homini, ille autem irreuerentiam et iniuriam maximam facit Deo et homini, immaculatum in maculatam animam et corpus suscipiens contra Dei sententiam, que diffinit quod peccatum separat hominem a Deo. Suscipiens uero eukaristiam in peccato mortali coniungit, Deum anime peccatrici in magnam displicentiam Dei peccata odientis et abhominantis.

32

\section{Passio}

Postquam serui Pilati Dominum Iesum conspuissent, acceperunt arundinem et percusserunt caput eius, ut spine capiti fortius infigerentur.

\section{Conformatio}

Sic fratres caueatis ne caput Christi arundine percutietis $\left[\mathrm{W}^{2}\right.$ f. $66 \mathrm{r}$ ] quod fit, quando uitam otiosam ducitis nec legentes nec meditantes nec orationi uacantes, que necessaria sunt omnibus religiosis ${ }^{\mathrm{CIX}}$, qui ab operibus exterioribus uictum et amictum conferentibus sunt sequestrati. Nam sic faciendo exempla a Christo habuimus, qui numquam otiosus fuit, sed semper fuit in labore multiplici predicationis doctrine, orationis et aliis quam plurimis et otiositas in uerbo et factis sibi semper displicet. Vnde de uerbo otioso predixit rationem esse reddendam $^{\mathrm{CX}}$. Facta etiam otiosa reprehendit cum
Ten opluwa twarz Chrystusa, kto w grzechu śmiertelnym Go przyjmuje. Albowiem Najświętszy pragnie mieszkać wśród świętych. Stąd świątynie są poświęcane, aby godnie w nich zamieszkiwal. Kto więc święty przybytek Boga, którym wy jesteście, zanieczyszcza i Chrystusa w sakramencie Eucharystii przyjmuje, bardziej zuchwale czyni niż Żydzi i poganie, którzy materialną twarz Chrystusa śliną plamili. Albowiem tamci uważali, że znieważają czystego człowieka, a on czyni największą zniewagę i krzywdę Bogu i człowiekowi, Niepokalanego do splamionej duszy i ciała przyjmując przeciwko woli Boga, co oznacza, że grzech oddziela człowieka od Boga. Przyjmując zaś Eucharystię $\mathrm{w}$ grzechu śmiertelnym, łączy Boga z grzeszną duszą ku wielkiemu niezadowoleniu Boga, który nienawidzi grzechów i nimi gardzi.

\section{2}

\section{Passio}

Po tym, jak słudzy Piłata opluli Pana Jezusa, wzięli trzcinę i uderzali Jego głowę, aby ciernie mocniej się w nią wbijały.

\section{Conformatio}

Tak, bracia, strzeżcie się, abyście nie uderzali trzciną głowy Jezusa, co dzieje się, gdy wiedziecie życie leniwe, nie czytając, nie rozmyślając i nie modląc się, co jest konieczne dla wszystkich zakonników [w oryg. „każdego zakonnika”], którzy nie są przydzieleni do prac zewnętrznych - gromadzenia wiktu i przyodziewku. Albowiem są przykłady takiego postępowania u Chrystusa, który nigdy nie był leniwy, lecz zawsze podejmował wiele trudów: głoszenie nauki, modlitwę i inne, bardzo liczne, bezczynność natomiast $\mathrm{w}$ słowie $\mathrm{i} \mathrm{w}$ czynach nigdy $\mathrm{Mu}$ się nie podobała. Dlatego o słowie niepotrzebnym 
dixit 'Quid statis hic tota die otiosi' ${ }^{\text {CXI }}$. Si ergo fratres otio uacabitis, harundine, quod est quid uacuum, Christum, qui est caput nostrum, percutitis siue offenditis. Et non loquor de otio contemplationis de quo Psalmista dicit 'Vacate et uidete quoniam suauis est Dominus ${ }^{\text {'CXII }}$, sed loquor de otio cessationis a bono et honesto et utili.

\section{Passio [ $W^{1}$ f. 137r]}

Postquam Dominus Iesus multipliciter a seruis Pilati illusus fuisset, aduxit eum foras Pilatus ostendens eum Iudeis coronatum spinea corona, ueste purpurea indutum et sceptro harundineo in dextera manu circumdatum, quod fuit lamentabile spectaculum. Nec sic Iudeis fuit satis factum.

\section{Conformatio}

Sic fratres ex quo Christus fuit in uestitu illusus, non gloriemur nos in ueste et apparatu exteriori. Hinc regula nostra dicit 'Non sit notabilis habitus uester nec affectetis uestibus place$\mathrm{re}^{\text {,CXIII }}$, sed gloria nostra sit in hoc, ut Christum illusum sequemur in habitu humili et despectu. $\mathrm{Nec}$ de corona capitis seu tonsura erubescere debemus $^{\mathrm{CXV}}$, ex quo Christus ostensus est Iudeis cum corona spinea coronatus. Imo gaudere debemus, ut cum talibus insigniis legalibus mistice acceptis possemus ante conspectum regis nostri in iudicio comparare. Quod enim in hoc mundo tamquam uile proicitur, hoc frequenter a summo bono eligitur et eius dilectione singulari decorari meretur. Nam Lazarus hic abiectissimus meruit angelicis manibus ad sinum Habrahe deportari. powiedział, że trzeba będzie zdać sprawę. Czyny niepotrzebne zganił, gdy rzekł: „Co tu stoicie cały dzień próżnując?” Jeśli więc, bracia, oddajecie się lenistwu, trzciną, która jest czymś próżnym, Chrystusa, który jest naszą głową, uderzacie albo obrażacie. I nie mówię o odpoczynku od kontemplacji, o którym mówi psalmista: „Bądźcie bezczynni, i zobaczcie, iż słodki jest Pan”, lecz mówię o odpoczynku od opieszałości w dobrym, szlachetnym i pożytecznym.

\section{3}

\section{Passio}

Po tym, jak Jezus został wielokrotnie wyszydzony przez sługi Piłata, Piłat wyprowadził Go na zewnątrz, pokazując Go Żydom ukoronowanego koroną cierniową, odzianego w płaszcz purpurowy i z trzcinowym berłem w prawej ręce, co stanowiło godne pożałowania widowisko. I tego nie było Żydom dosyć.

\section{Conformatio}

Tak, bracia, ponieważ Chrystus został wyszydzony $\mathrm{w}$ odzieniu, nie chlubmy się strojem i zewnętrznym przepychem. Stąd nasza reguła mówi: „Niech nie będzie okazałe wasze odzienie ani też nie starajcie się podobać ze względu na wasze szaty"CXIV, lecz chwała nasza niech będzie w tym, że podążamy za wyszydzonym Chrystusem w nędznym i lichym habicie. Nie powinniśmy również wstydzić się korony na głowie, czyli tonsury, ponieważ Chrystus został pokazany Żydom w koronie cierniowej. Szczególnie powinniśmy się cieszyć, że z tak stosownymi znakami, symbolicznie przyjętymi, możemy stawać przed obliczem naszego króla. Co na tym świecie jest porzucane jako marne, to wielokrotnie jest wybierane przez najwyższe dobro i zasługuje, żeby być obdarzone szczególną miłością. 
34

\section{Passio}

Quamquam Dominum Iesum Pilatus ostendisset Iudeis illusum, flagellatum et multis obprobriis uexatum, tamen non contenti circa horam tertiam clamabant 'Crucifige, crucifige eum! ${ }^{\text {CXVI }}$.

\section{Conformatio}

Sic fratres nolite paruipendere apertionem lingue contra proximum. Nam etsi Iudei manu non crucifixissent Dominum, tamen quia conclamabant atrociter, ut crucifigeretur, eis pro crucifixione reputatur. Hinc Marcus dicit Dominum crucifixum hora tertia, qui fuit tantum in clamore Iudeorum dicentium 'Crucifige, crucifige eum! ${ }^{\text {CXVII }}$ Et sic lingue Iudeorum fuerunt necatores Christi magis quam manus militum, quia non differt quantum ad culpe intensionem occidere hominem lingua an gladio. Vnde Psalmista 'Lingua eorum gladius acutus ${ }^{\text {CXVIII }}$. Et loquitur ad litteram de Iudeis clamantibus 'Crucifige'. Super quo Augustinus 'Noli attendere inermes manus, sed os armatum inde gladius processit, quo Christus occideretur ${ }^{\text {CXIX }}$. Consideratis igitur fratres, quod si lingua uestra alicui procurat malum, tantum ei nocetis, quantum manu id faceretis. Inde est, quod irregulares efficiuntur, qui sentenciant homines $\left[\mathrm{W}^{1}\right.$ f. $\left.137 \mathrm{v}\right]$ ad mortem etiam si manum non apponant. Parcite igitur linguis fratres, ne contra proximum loquendo crucifixores efficiemini cum Iudeis, qui linguis Christum crucifixerunt.
Albowiem Łazarz, ten najmarniejszy, zasłużył, aby być zaniesiony rękami anielskimi na łono Abrahama.

\section{4}

\section{Passio}

Chociaż Piłat wyszydzonego, biczowanego i udręczonego licznymi zniewagami pokazał Pana Jezusa Żydom, jednak oni niezadowoleni około godziny trzeciej krzyczeli: „Ukrzyżuj, ukrzyżuj Go!'

\section{Conformatio}

Tak, bracia, nie lekceważcie użycia języka przeciw bliźniemu. Albowiem chociaż Żydzi nie ukrzyżowali Pana rękami, jednak, ponieważ zawzięcie krzyczeli, aby został ukrzyżowany, im przypisuje się ukrzyżowanie. Stąd Marek mówi, że Pan został ukrzyżowany o godzinie trzeciej wśród Żydów krzyczących: „Ukrzyżuj, ukrzyżuj Go!” I tak języki Żydów były zabójcami Chrystusa bardziej niż ręce żołnierzy, ponieważ nie ma różnicy między ciężarem winy za zabójstwo człowieka językiem a mieczem. Dlatego psalmista [mówi]: „ich język - miecz ostry”. I mówi dosłownie o Żydach wołających: „Ukrzyżuj”, na co Augustyn: „Nie patrz na nieuzbrojone ręce, ale na usta zbrojne. Stamtąd wydobyto miecz, którym zabito Chrystusa"CXX. Rozważcie więc bracia, że jeśli wasz język zarzuca komuś niegodziwość, tak bardzo mu szkodzicie, jakbyście to czynili ręką. Stąd pochodzi to, że skazują ludzi na śmierć, nawet jeśli nie przyłożyli ręki. Oszczędzajcie więc języki, bracia, abyście mówiąc przeciwko bliźniemu, nie stali się oprawcami razem z Żydami, którzy ukrzyżowali Chrystusa językami. 
35

\section{Passio}

Postquam Dominum Iesum Pilatus uoluisset dimittere, Iudei clamabant 'Si hunc di- [W' f. 66v] mittis, non es amicus cesaris ${ }^{\text {'XXI }}$. Ad quem clamorem Pilatus adduxit Iesum foras et sedit pro tribunali.

\section{Conformatio}

Sic fratres conformemini uos Christo, ut tempore aduersitatis iudicium Dei cum patientia subiatis. Nam et Christus ante tribunal Pilati obmutuit et non aperuit os suum. Vnde tempore aduersitatis ante tribunal Dei sistemini, ut cum patientia sufferatis, que uobis inferuntur, que in penis, quia tales pene sunt purgamenta peccatorum. Quia ut Apostolus ait 'Cum iudicamur scilicet temporalibus penis hoc fit ne cum hoc mundo dampnemur' ${ }^{\text {CXXII. }}$ Etiam fratres de uobismetipsis facite tale iudicium, quale faciat Christus in futuro ultimo iudicio, qui condempnabit malos et saluabit bonos secundum illud Athanasy in Simbolo 'Qui bona egerunt, ibunt in uitam eternam,

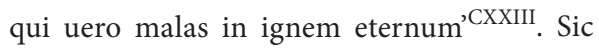
etiam uos condempnetis mala opera contra legem Dei et professionem uestram et saluetis bona ipsa continuando. Et quamuis semper regulariter uiuere sit uita dura et sensualitati penitus contraria, tamen est multum meritoria et ad uitam eternam inductiua, quia uia ducens ad uitam est arta ut os ueritatis dicit, sed tamen est secura et compendiosa. Et de tali proprio iudicio loquitur Apostolus dicens 'Si nosmetipsos diiudicaremus non utique diiudicaremur' ${ }^{\text {CXXV }}$.
35

\section{Passio}

Po tym, jak Piłat chciał uwolnić Pana Jezusa, Żydzi krzyczeli: „Jeśli Tego wypuścisz, nie jesteś przyjacielem cesarskim”. Na ten krzyk Piłat wyprowadził Jezusa na zewnątrz i zasiadł na trybunale.

\section{Conformatio}

Tak, bracia, upodabniajcie się do Chrystusa, abyście w czasie przeciwności przyjęli wyrok Boga z cierpliwością. Albowiem i Chrystus przed trybunałem Piłata zamilkł i nie otworzył swoich ust. Dlatego w czasie przeciwności przed trybunałem Boga stańcie, abyście z cierpliwością znieśli to, co jest wam zarzucane, oraz kary, ponieważ są to kary za brudy grzechów. Gdyż jak mówi apostoł: „Gdy jesteśmy skazywani (na kary doczesne), dzieje się to, abyśmy nie byli potępieni z tym światem”. Również, bracia, sobie samym czyńcie taki sąd, jaki w przyszłości uczyni na sądzie ostatecznym Chrystus, który potępi złych i zbawi dobrych. Według tego Atanazy w Symbolu: „A którzy dobrze czynili, pójdą na żywot wieczny, którzy zaś źle - na ogień wieczny"CXXIV. Tak również wy potępiajcie złe uczynki przeciwko prawu Bożemu i waszej profesji i zbawiajcie się, stale czyniąc dobro. I chociaż zawsze żyć zgodnie z regułą oznacza życie trudne i przeciwne wewnętrznej zmysłowości, jednak przynosi liczne zasługi i prowadzi do życia wiecznego, ponieważ droga prowadząca do życia jest wąska, jak mówią usta prawdy, lecz mimo to jest bezpieczna i krótkotrwała. I o tym własnym sądzie mówi apostoł: „gdybyśmy się sami sądzili, nie bylibyśmy sądzeni”. 
36

\section{Passio}

Postquam Pilatus non potuit efficere apud Iudeos, ut Dominum Iesum liberaret, lotis manibus sententiauit Christum innocentem et iustum ad mortem, que sententia secundum Euangelium Nicodemi fuit hec 'Gens tua approbauit te regem propterea precipio te primum flagellari secundum principum statuta deinde cruce eleuari' $^{\text {CXXVI. }}$.

\section{Conformatio}

Sic fratres etsi aliquando iniquam sententiam sustinueritis, tamen propter hoc in animo non debetis deici et conturbari, sed memores estote Domini uestri Iesu Christi, qui ualde iniquam sententiam absque contradictione patienter sustinuit, quia talis iniqua sententia [W ${ }^{1}$ f. 138r] etsi ligat apud homines, tamen non apud Deum, quia sepius quos homines dampnant inique, Deus saluat ${ }^{\text {CXXVIII }}$ ut clare patet in dampnatione martirum per tyrannos, quos tamen Deus iustissime saluauit. Hinc Apostolus ait sententiam iniquam paruipendens 'Michi pro minimo est, ut iudicer'CCXXIX . Similiter fratres summe caueatis, ne sitis Pilatus in iudicando bonos et iustos, ascribendo eis ypocrisim, singularitatem uel alias causas falsas. Nam in talibus iudiciis sepius Deus offenditur. Hinc Psalmista dicit 'Recte iudicate filii hominum, ${ }^{{ }^{C X X X}} \mathrm{Nam}$ ex talibus iudiciis sequitur paruipensia personarum et caritas proximi minoratur.

37

\section{Passio}

Postquam Dominus Iesus condempnatus fuisset, milites Pilati exuerunt eum purpura et in-
36

\section{Passio}

Po tym, jak Piłat nie mógł u Żydów sprawić, żeby uwolnić Pana Jezusa, umywszy ręce skazał Chrystusa niewinnego i sprawiedliwego na śmierć. Według Ewangelii Nikodema wyrok brzmiał tak: „Lud twój zasądził cię jako króla, dlatego też rozkazałem najpierw cię ubiczować, wedle rozkazów pobożnych cesarzy, a następnie powiesić na krzyżu”CXXVII.

\section{Conformatio}

Tak, bracia, chociaż kiedyś znosiliście niesłuszny wyrok, jednak nie powinniście $\mathrm{z}$ tego powodu burzyć się i niepokoić, lecz pamiętajcie o Panu naszym Jezusie Chrystusie, który bardzo niesprawiedliwy wyrok zniósł cierpliwie i bez sprzeciwu, ponieważ tak niegodziwy wyrok, chociaż jest wiążący u ludzi, jednak nie u Boga, gdyż częściej tych, których ludzie niesłusznie potępiają, Bóg ocala, co wyraźnie widać w przypadku skazanych przez tyranów męczenników, których Bóg mimo to sprawiedliwie zbawił. Stąd apostoł lekceważąc niesprawiedliwy wyrok, mówi: „Dla mnie najmniejsza to rzecz, żebym był sądzony”. Podobnie, bracia, przede wszystkim strzeżcie się, abyście nie byli Piłatami w osądzaniu dobrych i sprawiedliwych, przypisując im obłudę, bezżenność lub inne fałszywe winy. Albowiem w takich sądach bardzo często obraża się Boga. Stąd psalmista mówi: „Sądźcież sprawiedliwie, synowie człowieczy!” Albowiem za takimi sądami podąża pogarda dla osób, a miłość bliźniego słabnie.

\section{7}

\section{Passio}

Po tym, jak Pan Jezus został skazany, żołnierze Piłata zdjęli z niego purpurę, ubrali Go w Jego 
duerunt eum uestimentis suis et imposuerunt sibi crucem portandam ad locum passionis.

\section{Conformatio}

Sic fratres crucem Domini iugiter portare debetis, si uiri perfecti et imitatores Christi esse desideratis. Et hoc faciendum ostendit natura. Nam ut dicit Ieronymus super Marcum 'Aues quando uolant ad ethera, formam crucis assumunt. Homo etiam natans forma crucis uehi-

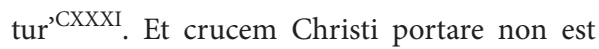
intelligendum seu faciendum litteraliter sicut quidam monachi fecerunt, qui sibi cruces ligneas faciebant et secum semper portabant, sed intelligendum est mistice et spiritualiter. Nam Christi crucem portare est eius uestigia sequi, ut $\left[\mathrm{W}^{2}\right.$ f. $\left.67 \mathrm{r}\right]$ et nos ambulemus sicut ipse in mundo ambulauit uitam artissimam dicendo, ut tota series Euangelii testatur. Et hanc crucem fratres karissimi non debetis portare angustiati et inuoluntarie sicut Symon portauit. Nec cum Symone debetis portare crucem alienam, sed propriam. Hinc saluator ait Lucas IX 'Si quis uult uenire post me, tollat crucem suam'. Tunc fratres portatis crucem alienam et non propriam, quando abstinentiam aliis predicatis et in uobis minime seruatur. Contra quos dicit Bernhardus 'Ve portantibus crucem non sicut saluator suam, sed sicut [ $\mathrm{W}^{1}$ f. $138 \mathrm{v}$ ] Cireneus

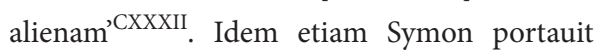
crucem Christi, attamen non moriebatur. Sic fratres uos facitis si iugum ordinis portatis, sub quo tamen adhuc uiuitis mundo id est mundana appetendo. Sic non portauit Apostolus crucem Christi, qui ait 'Michi mundus cruci-

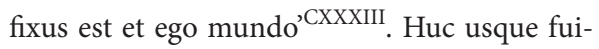
mus cum Domino nostro in domibus impiorum et ciuitate, nunc exeamus foras cum Ipso in campum. szaty i dali Mu krzyż, aby go niósł na miejsce męki.

\section{Conformatio}

Tak, bracia, powinniście stale nosić krzyż Pana, jeśli pragniecie być doskonałymi mężami i naśladowcami Chrystusa. Takie postępowanie pokazuje natura. Albowiem jak mówi Hieronim Super Marcum: „Ptaki, kiedy wzlatują w niebo, przybierają kształt krzyża. Człowiek również płynąc, porusza się, przybierając kształt krzyża”. Noszenia krzyża Chrytusa nie można rozumieć lub czynić dosłownie, jak pewni mnisi, którzy wykonywali sobie drewniane krzyże i zawsze ze sobą nosili, lecz trzeba rozumieć symbolicznie i duchowo. Albowiem nieść krzyż Chrystusa to podążać Jego śladami, abyśmy i my chodzili, jak On sam chodził na świecie, mówiąc o najtrudniejszym życiu, aby cała treść Ewangelii została poświadczona. I tego krzyża, bracia najdrożsi, nie powinniście nieść udręczeni i niechętni jak Szymon. Nie powinniście także z Szymonem nieść cudzego krzyża, lecz własny. Stąd zbawiciel mówi w Ewangelii według św. Łukasza 9: „Jeśli kto chce iść za Mną, niech weźmie krzyż swój”. Wtedy, bracia, niesiecie krzyż cudzy i nie własny, kiedy innym głosicie powściągliwość, a w was $\mathrm{w}$ ogóle nie jest ona zachowana. Przeciwko takim mówi Bernard: „Biada niosącym krzyż nie własny jak Zbawiciel, lecz cudzy jak Cyrenejczyk”. Tak samo również Szymon niósł krzyż Chrystusa, a jednak nie umarł. Tak bracia wy czynicie, jeśli bierzecie na siebie jarzmo zakonu, pod którym jednak ciągle żyjecie na świecie, czyli staracie się o rzeczy ziemskie. W ten sposób nie niósł krzyża Chrystusa apostoł, który mówi: „świat jest mi ukrzyżowany, a ja światu”. Do tego momentu byliśmy z Panem naszym $\mathrm{w}$ domach 
$<38>$

\section{Passio}

Postquam Domino Iesu imposuerunt crucem super humerum eius, duxerunt eum extra ciuitatem in locum, qui dicitur Golgata ad crucifigendum.

\section{Conformatio}

Sic fratres sicut Christus uoluntarie ductus est ad patibulum tamquam ouis ad uictimam, sic et uos uoluntarie duci debetis ad obedientiam mandatorum Dei et prelatorum, qua propria uoluntas mactatur, ut cum Psalmista dicatis 'Deduc me Domine in semita mandatorum

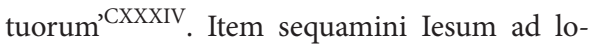
cum passionis flendo cum mulieribus miseriam nostre fragilitatis et pronitatem ad peccandum. Quando etiam fratres itinera facitis usque ad lassitudinem ex obedientia, mementote processionis Christi seu ambulationis ad crucem, in qua Dominus noster ita lassus fuit per crucem, quod eam amplius per se portare non poterat. Nec mirum, quia per totam noctem diemque illum multipliciter fatigatus fuit. Gratias etiam agatis Iesu saluatori uestro, quod tam ignominiosa pro uestra gloria passus est, ut ad patibulum quasi fur et latro duceretur. Hinc duo latrones cum eo ducebantur ad maiorem ipsius confusionem. Quia quamuis Christum propter alia beneficia, que nobis contulit, adorare debeamus, tamen propter contumelias passas ex animo adoretur, quia tantum pro nobis condescendere dignatus est, ut hec passus in omni nos uirtutis genere institueret ${ }^{\mathrm{CXXXV}}$ ut dicit Crisostomus super Mattheum. Quis enim humilitatem et patientiam non indueret ac confusionem sustineret, qui bezbożników i w mieście, teraz wychodzimy z Nim na zewnątrz na pole.

$<38>$

\section{Passio}

Po tym, jak włożyli Mu krzyż na barki, zaprowadzili Go poza miasto na miejsce, które nazywa się Golgota, aby Go ukrzyżować.

\section{Conformatio}

Tak, bracia, jak Chrystus dobrowolnie został zaprowadzony na krzyż, jak owca na ofiarę, tak i wy powinniście dobrowolnie być prowadzeni do posłuszeństwa wobec przykazań Boga i przełożonych, dzięki któremu poświęca się własną wolę, abyście mówili z psalmistą: „Prowadź mię, Panie, ścieżką przykazań Twoich”. Podobnie podążajcie za Jezusem na miejsce męki, opłakując z kobietami nieszczęście naszej ułomności i skłonność do grzechu. Kiedy także, bracia, podróżujecie $\mathrm{w}$ posłuszeństwie aż do znużenia, pamiętajcie o pochodzie albo drodze na krzyż, w czasie której tak Pan nasz był wyczerpany przez krzyż, że nie mógł dalej sam go nieść. Nic dziwnego, ponieważ przez całą noc i tamten dzień wielokrotnie był dręczony. Dziękujcie więc waszemu Zbawicielowi, że zniósł taką hańbę dla waszej chwały, że na krzyż jak złodziej i złoczyńca był prowadzony. Dlatego szli z Nim dwaj łotrzy, aby bardziej Go zawstydzić. Chociaż powinniśmy wielbić Chrystusa z powodu wielu łask, które nam zesłał, jednak szczerze trzeba Go czcić z powodu wycierpianych zniewag, ponieważ na tak wiele za nas raczył się zgodzić, że to wycierpiawszy we wszystkich rodzajach cnoty nas pouczył, jak mówi Chryzostom Super Matthaeum. Któż bowiem nie przybrałby pokory i cierpienia 
uideret Dominum glorie tamquam $\left[\mathrm{W}^{1} \mathrm{f} .139 \mathrm{r}\right]$ latronem ad patibulum duci.

$<39>$

\section{Passio}

Postquam Dominus Iesus adductus esset ad locum passionis, spoliauerunt eum uestibus suis et precinxerunt eum linteo ${ }^{\mathrm{CXXVI}}$ ut legitur in Euangelio Nicodemi. Et bene ista particula ad passionem Christi pertinet, quia magna pena est expoliari coram omni populo.

\section{Conformatio}

Sic fratres sicut Christus uestibus spoliatus est antequam crucem ascenderet, debetis uos spoliare seu denudare ab omnibus rebus et operibus mundanis, ut nudum crucifixum nudi sequamini. Paupertatem enim et omnem penuriam propter Christum diligere debetis et de temporalibus nisi strictam necessitatem non queratis aut appetatis et inquantum $\left[\mathrm{W}^{2} \mathrm{f} .67 \mathrm{v}\right]$ inueneritis uos habundantes in cibo et potu, in uestitu et consolationibus corporis, tanto magis contristari debetis eo quod elongati sitis a Christi nuditate. $\mathrm{Nec}$ estis ueraciter nudi etsi careatis rebus temporalibus paupertate oppressi, si animus uester temporalia concupiscat. Nam si cupiditate uincemini temporalium, quomodo concupiscentias carnis superabitis? Concupiscentia enim carnis sequitur complexionem corporis, sed affectio rerum temporalium minime, ideo facilius uincitur concupiscentia temporalium, quam concupiscentia carnis. Ad ueram autem sequelam nuditatis Christi non tantum requiritur denudatio corporalium, sed magis denudatio animi a noxiis concupiscentiis. Si etiam uos spoliari aliquibus rebus contingat, Christum Dominum in mentem uestram constituite, qui spoliatus est a crucifixoribus et erit uobis materia patientie. i nie zniósłby zmieszania, kto zobaczyłby Pana chwały prowadzonego na krzyż jak łotra.

$<39>$

Passio

Po tym, jak Jezus został przyprowadzony na miejsce męki, odarli Go z Jego szat i opasali chustą, jak czyta się w Ewangelii Nikodema. I dobrze ta cząstka odnosi się do Pasji Chrystusa, ponieważ wielką karą jest obnażyć kogoś wobec ludu.

\section{Conformatio}

Tak, bracia, jak Chrystus odarty z szat, zanim wstąpił na krzyż, powinniście się pozbawić lub ogołocić ze wszystkich rzeczy i zajęć ziemskich, abyście nadzy podążali za nagim krzyżem. Powinniście kochać wszelkie ubóstwo i niedostatek ze względu na Chrystusa i nie szukajcie, ani nie zabiegajcie o rzeczy doczesne, chyba że ze ścisłej konieczności, i o ile bardziej znajdziecie nadmiar pokarmu i napojów, ubioru i uciech cielesnych, o tyle bardziej powinniście smucić się tym, że jesteście oddaleni od nagości Chrystusa. Nie jesteście również prawdziwie nadzy, chociaż brakuje wam rzeczy doczesnych z powodu ubóstwa, jeśli wasz umysł ich pożąda. Jeżeli bowiem zostaniecie zwyciężeni przez pragnienie rzeczy doczesnych, jak pokonacie pożądanie cielesne? Pożądanie bowiem cielesne podąża za skłonnościami ciała, a przywiązanie do rzeczy doczesnych wcale nie, dlatego łatwiej zwyciężone zostaje pragnienie rzeczy doczesnych niż pożądanie cielesne. Do prawdziwego skutku nagości Chrystusa konieczne jest nie tylko wyzbycie się spraw cielesnych, lecz raczej ogołocenie duszy ze szkodliwych pożądań. Jeśli nawet zdarzy się wam być odartym $\mathrm{z}$ innych rzeczy, zatrzymajcie w waszym umyśle Chry- 
$<40>$

\section{Passio}

Postquam Dominum Iesum expoliassent, parata iam cruce ita ${ }^{\mathrm{CXXXVII}}$ atrociter eum extenderunt, ut omnia ossa eius possent numera$\mathrm{ri}^{\mathrm{CXXXVIII}}$.

\section{Conformatio}

Sic fratres omnia membra uestra et organa corporis extendere debetis in obsequium Christi. Iam ueniam faciendo in secreto, iam manus leuando ad ${ }^{\text {CXXXIX }}$ celum et occulos, iam manus extendendo in modum crucis etc. Et hac mente referre debetis ad configurandum uos Christo patienti. Nam in extensione crucis maximum dolorem sustinuit ut ipse reuelauit cuidam deuote persone dicens 'Quando in cruce extensus fui ita, quod omnia ossa mea $\left[\mathrm{W}^{1}\right.$ f. 139v] numerari poterant, dolorem maximum habui ${ }^{\mathrm{CXL}}$ et quicumque pro isto dolore michi gratias egerit ita gratum obsequium michi prestabit ac si omnia uulnera mea unguento suauissimo diliniret ${ }^{\text {CXLI }}$. Gratias igitur agatis Domino extenso in cruce mente et corpore, ut extensio uestra cum cordis extensis in citara reddet bonum sonum. Considerate etiam fratres Christum extensum in mente uestra et eius maximum amorem ad homines perpendite, qui in amplexus suos uult omnes recipere. Hinc Augustinus ait 'Christus ${ }^{\text {CXLII }}$ brachia sua extendit in cruce et expandit ${ }^{\text {CXLIII }}$ manus suas paratas in amplexus peccatorum. Inter brachia saluatoris mei et uiuere uolo et mori cupio. Ibi securus cantabo: Exaltabo te Domine, quoniam suscepisti me ${ }^{\text {CXLIV }}$. stusa, który został obnażony przez oprawców i On będzie dla was źródłem cierpliwości.

$<40>$

\section{Passio}

Po tym, jak Pana Jezusa odarli z odzienia, rozciągnęli Go na przygotowanym już krzyżu tak okrutnie, że można było policzyć wszystkie Jego kości.

\section{Conformatio}

Tak, bracia, wszystkie wasze członki i narządy ciała powinniście rozpościerać w posłuszeństwie Chrystusowi. Albo czyniąc łaskę w ukryciu, albo podnosząc ku niebu ręce i oczy, albo rozciągając ręce na kształt krzyża etc. $\mathrm{Z}$ taką myślą powinniście odnosić się do naśladowania Chrystusa cierpiącego, ponieważ rozpostarty na krzyżu zniósł największy ból, jak sam objawił pewnej pobożnej osobie, mówiąc: „Kiedy byłem tak rozciągnięty na krzyżu, że można było policzyć wszystkie moje kości, odczuwałem największy ból i ktokolwiek będzie mi tak dziękował za ten ból, okaże mi miłe posłuszeństwo, jakby wszystkie moje rany najłagodniejszym olejem namaścił”. Dziękujcie więc Panu rozpiętemu na krzyżu umysłem i ciałem, aby wasze rozciągnięcie ze strunami naciągniętymi w cytrze dawało ładny dźwięk. Rozważajcie więc bracia Chrystusa rozciągniętego w waszych sercach i rozważajcie Jego wielką miłość do ludzi, który w swoje objęcia chce wszystkich przyjąć. Stąd Augustyn mówi: "Chrystus rozciągnął swoje ramiona na krzyżu i rozłożył swoje ręce gotowe na przyjęcie grzeszników. W ramionach mojego Zbawiciela chcę żyć i umierać pragnę. Tu bezpiecznie zaśpiewam: "Wysławiać cię będę, Panie, żeś mię przyjął»". 
$<41>$

Passio

Postquam Dominum Iesum in cruce extendissent, affixerunt eum cruci durissimis clauis in manibus et pedibus.

\section{Conformatio}

Sic fratres configere debetis manus uestras et pedes ac totam carnem cruci Domini, ut nec manus uestre sint solute ad faciendum prohibita nec pedes id est affectiones sint libere ad affectandum mala. Quando enim temptatio trahit uos ad faciendum contra precepta uel quando affectio carnalium uoluptatum uos uexat, crucem uobis faciatis et clauo preceptorum et timoris ipsi ${ }^{\mathrm{CXLV}}$ cruci uos affigatis, ut sic semper pendeatis in cruce obseruatione preceptorum et timore Dei. Si enim transgressio uel uoluptas uos temptat, clauo timoris talia excutite, ne Dominum pietatis uel benefactorem offendatis et penam perpetuam inferni incurratis. Hinc Apostolus suadet carnem nostram crucifigi cum uitiis et concupiscentiis. Et de seipso dicit ad Galatas 2 'Christi confixus sum cruci' ${ }^{\text {CXLVI }}$ et Psalmista 'Confige timore tuo carnes meas ${ }^{\text {CXLVII }}$. Quando enim caro desiderat noxia, configenda $\left[\mathrm{W}^{1}\right.$ f. $\left.140 \mathrm{r}\right]$ est seu retrahenda timore Dei. Et sicut Christus sua sinistra manu [ $\mathrm{W}^{2}$ f. $68 \mathrm{r}$ ] in cruce extensa omnia mala nostra apprehendit et destruxit ${ }^{\text {CXLVIII }}$ ut Ieronymus dicit, sic uos omnes tribulationes uestras, temptationes, infirmitates, aduersitates, culpas et penas in dulcissimo uulnere sinistri manus reponere debetis ipsam osculando supplicando crucifixo, ut etiam uestra mala a uobis remoueat. Sic fecit Augustinus qui ait 'Cum me pulsat aliqua turpis cogitatio, precurro ad uulnera Christi' ${ }^{\text {CXLIX }}$. Bona etiam uestra non uobis, sed dextere Dei uobis condonantis
$<41>$

\section{Passio}

Po tym, jak rozpięli na krzyżu Pana Jezusa, przybili Go za ręce i nogi najtwardszymi gwoździami.

\section{Conformatio}

Tak, bracia, powinniście przybić wasze ręce, nogi i całe ciało do krzyża Pana, aby ani wasze ręce nie mogły swobodnie czynić tego, co zabronione, ani stopy, czyli uczucia, nie były wolne w czynieniu zła. Kiedy bowiem pokusa przyciąga was do czynienia wbrew przykazaniom albo kiedy dręczy was pożądanie uciech cielesnych, uczyńcie sobie krzyż i gwoździem przykazań i bojaźni do niego się przybijcie, abyście tak zawsze wisieli na krzyżu przestrzegania przykazań i bojaźni Bożej. Jeśli bowiem kusi was wykroczenie lub przyjemność, przebijcie je gwoździem bojaźni, abyście nie obrazili Pana pobożności i dobroczyńcy i nie ściągnęli na siebie wiecznej kary piekła. Stąd apostoł doradza ciało nasze ukrzyżować z wadami i pożądaniem i o tym mówi do Galatów 2: „Z Chrystusem jestem przybity do krzyża” i psalmista: „Przebij bojaźnią Twoją ciało moje”. Kiedy bowiem ciało pragnie szkody, trzeba je ukrzyżować albo powstrzymać bojaźnią Bożą. I tak jak Chrystus swoją lewą ręką rozciągniętą na krzyżu wszystkie nasze niegodziwości zabrał i zniszczył, jak mówi Hieronim, tak wszystkie wasze strapienia, pokusy, słabości, przeciwności, winy i kary w najmilszej ranie lewej ręki powinniście złożyć, całując ją i klęcząc pod krzyżem, aby także wasze niegodziwości od was odsunął. Tak uczynił Augustyn, który mówi: „Kiedy dręczy mnie jakaś haniebna myśl, biegnę do ran Chrystusa”. Również wasze zalety przypisujcie nie sobie, lecz prawicy Boga, która was obdarowuje, i złóżcie 
ascribite et in uulnere dextere manus reponatis, ut ibi conseruentur. Et sicut cum operibus currere debetis ad manus Christi, ut scilicet per sinistram remoueantur mala et per dexteram conseruentur bona, sic cum desideriis prauis, ut curentur, recurratis ad uulnus sinistri pedis et, ut bona conseruentur, ad uulnus dexteri pedis. Omnia enim bona uestra nichil ualent, nisi intingantur in sanguine uulneris Christi id est nichil ualerent ratione meriti extra meritum Christi. Hinc glosa super illud 'Foderunt manus meas ${ }^{\text {'CL }}$ dicit 'Sicut terra fossa fructum facit, sic fructum uite dedit Christus uulneratus in manibus et pedibus' ${ }^{\text {CLI }}$. $\mathrm{Ob}$ tanta igitur beneficia osculantur sepius uulnera Christi crucifixi manuum et pedum. Et quamuis possibile sit, quod dextera manus prius quam sinistra perforata sit et dexter pes superpositus sinistro prius transfixus sit uno clauo, tamen uos conformando his membris osculari debetis primo sinistrum et deinde dextrum. Nam prius ${ }^{\text {CLII }}$ debetis dimittere malas affectiones et postea incipere bonas. Et prius debetis emendare mala, deinde facere bona. Et sic Maria Magdalena incepit osculum in pedibus Christi.

$<42>$

\section{Passio}

Postquam Dominum Iesum Christum crucifixissent cruce iacente in terra, postea eum affixum leuauerunt cum cruce. Hinc in die Parasceues crux iacet appodiata ad terram ad osculandum. Et ista eleuatio fuit maximi doloris, quia tunc dilacerabantur uulnera $\left[\mathrm{W}^{1}\right.$ f. 140v] manuum et pedum. Alii autem uolunt, quod Christus ascendisset per scalam ad crucem erectam et ibi crucifixus fuisset. je w ranie prawej ręki, aby tam były zachowane. I tak jak z uczynkami powinniście biec do rąk Chrystusa, aby przez lewą zostały usunięte niegodziwości, a przez prawą zachowane zalety, tak ze złymi pragnieniami, aby zostały uleczone, zwróćcie się do rany lewej stopy, i aby dobre rzeczy zostały zachowane, do rany prawej stopy. Wszystkie bowiem wasze zalety nic nie są warte, jeśli nie są zanurzone we krwi rany Chrystusa, to znaczy: nic nie są warci zasłużeni z powodu rozumu w oddaleniu od zasług Chrystusa. Stąd glosa do: „przebodli ręce moje” mówi: „Tak jak przekopana ziemia daje owoc, tak owoc życia daje Chrystus zraniony w ręce i nogi”. Z powodu tak wielkich łask należy częściej całować rany Chrystusa ukrzyżowanego za ręce i nogi. I chociaż możliwe jest, że prawa ręka została przekłuta wcześniej niż lewa i prawa stopa umieszczona nad lewą wcześniej została przebita jednym gwoździem, jednak wy powinniście iść za wzorem tych członków i najpierw całować lewą, potem prawą. Albowiem najpierw powinniście porzucić złe uczucia, a potem uzyskać dobre i wcześniej powinniście naprawić zło, następnie czynić dobro. I tak Maria Magdalena zaczęła całować Chrystusa w nogi.

\section{$<42>$}

\section{Passio}

Po tym, jak Pana Jezusa Chrystusa przybili do krzyża leżącego na ziemi, podnieśli Go razem z krzyżem. Dlatego w Wielki Piątek krzyż przeznaczony do całowania leży, opierając się na ziemi. Takie podniesienie wywoływało bardzo wielki ból, ponieważ wtedy szarpane były rany rąk i nóg. Inni zaś chcą, żeby Chrystus wspinał się po drabinie na stojący krzyż i tam został ukrzyżowany. 


\section{Conformatio}

Sic fratres mentes uestras in deuotione eleuetis sursum quasi Christo coram uobis pendente ei aliquid obsequium gestu corporis representate et moueamini ad conpassionem, quia sic de cruce loquitur ad nos Christus cum Fratre nostro Amando libro primo rubrica XV 'In illa hora cum mortis supplementum pertuli, anima uerbo perfecte fruebatur et tantum diuinitas permisit carni agere et pati que propria et quia uires inferiores sibi ipsis relinquebantur passibiles ualde reddebantur. Attende nunc iniuriam totius orbis in cruce suspensam et miseriis ultra modum angustiatam. Pendebam in patibulo crucis ligno immobiliter confixus, desolatus et omni adiutorio priuatus, sed et pater meus non iuuabat, quem iuuare poterat magnalia opera ostendendo. Vulnera cruenta sanguinem fundebant occuli mei a fletu caligabant et omnia uiscera mea pre nimio cruciatu contabescebant amare flebam et non erat qui lacrimas abstergeret ${ }^{\text {CLIII }}$. Fratres igitur karissimi uicem non tantam, quantam debetis, quia si omnium creaturarum uirtutes haberetis, rependere uicem tanto redemptore ex condigno non possetis nec pro minima sanguinis gutta ex amore pro uobis effusum, sed quantam potestis Christo [ $\mathrm{W}^{2}$ f. $68 \mathrm{v}$ ] rependite passionem Christi semper in corde uestro habentes.

$<43>$

\section{Passio}

Postquam Dominus Iesus crucifixus fuisset in medio duorum latronum et postquam milites uestimenta diuisissent et sortem misissent et titulus cruci affixus esset, tunc Christus com-

\section{Conformatio}

Tak, bracia, podnoście wasze umysły w pobożności, jak gdybyście znajdowali się w obecności wiszącego Chrystusa, wyrażajcie posłuszeństwo wobec Niego w gestach ciała i okazujcie współczucie, ponieważ tak z krzyża mówi do nas Chrystus z naszym Fratre Amando w księdze 1, w rozdziale 15: „W tamtej godzinie, kiedy byłem bliski śmierci, dusza całkowicie korzystała ze słowa i tylko boskość pozwoliła ciału czynić i cierpieć to, co właściwe, a ponieważ siły piekielne same sobie były pozostawione, mogły wywoływać wielkie cierpienia. Zważ teraz na niegodziwość całego świata zawieszoną na krzyżu i udręczoną nieszczęściami ponad miarę. Wisiałem na krzyżu, przybity nieruchomo do drzewa, opuszczony i pozbawiony wszelkiej pomocy, lecz także mój Ojciec nie wspierał tego, którego mógł wesprzeć, pokazując wielkie dzieła. Rany krwawiące wylewały krew, oczy moje ślepły od płaczu i wszystkie moje wnętrzności usychały z powodu zbyt wielkiej męki, gorzko płakałem i nie było takiego, który wstrzymałby łzy”. Zatem, bracia najdrożsi, nie na tyle, na ile powinniście, ponieważ gdybyście mieli cnoty wszystkich stworzeń, nie moglibyście odpowiednio wynagrodzić trudnego losu tak wielkiemu Odkupicielowi ani najmniejszej kropli krwi przelanej za was z miłości, lecz na tyle, na ile możecie, wynagradzajcie Chrystusowi trudny los, zawsze mając w sercach Jego Mękę.

$<43>$

\section{Passio}

Po tym, jak Chrystus został ukrzyżowany między dwoma łotrami, żołnierze podzielili szaty i rzucili losy, a tabliczka została przymocowana do krzyża, wtedy Chrystus powierzył Mat- 
mendauit matrem uirginem Iohanni. Et accepto aceto cum magno clamore animam patri commendauit.

\section{Conformatio}

Sic fratres si uitam artam obseruantie intentione placendi Deo obseruaueritis, eritis in dextera Christi cum bono latrone, cuius supplicia non erant inania. Si uero laudem humanam in obseruantia queritis, [ $\mathrm{W}^{1}$ f. 141r] eritis cum malo latrone a sinistris tormenta patiendo sine fructu. Vestimenta etiam Christi inter uos diuiditis, quando exempla sanctorum imitemini, que per uestimenta significantur. Et sicut Pilatus noluit mutare titulum passionis, sic uos non debetis delere ${ }^{\mathrm{CLIV}}$ de corde uestro memoriam passionis Christi. Et sicut Christus accepit acetum, sic in uobis omnia amara et acetosa fiant, que dulcia prius fuerunt, ut sic cum amarissima matre mereamini portiunculam condolentie siue maxime conpassionis crucifixi habere. Vt enim Iohannes meminit ipsa stabat iuxta crucem Iesu ${ }^{\mathrm{CLV}}$. O uerbum totius compassionis! Considerate igitur fratres, si amabile, quod a uobis maxime amaretur, traderetur confusibili morte, quantum ex hoc doleretis et compassionem haberetis? Sic cogitate de matre Iesu: quantis doloribus urgebatur stans sub cruce, quando dilectissimum, quem pre cunctis mortalibus amauit, uidit morte turpissima condempnatum? Multum enim dolebat, quia multum diligebat. Et causam doloris prebebat ${ }^{\mathrm{CLVI}}$, quia dum sursum occulos lacrimosos leuat, uidit dilectissimum suum suspensum, cui nec in aliquo solacium ferre potuit. Et dum respexit deorsum, uidit cum immenso dolore, qui filium eius crudeliter torquebant. Et pre maximo cruciatu corde prefata erat, quia crucifixus sibi cor abstulerat simul kę Dziewicę Janowi i przyjąwszy ocet, z wielkim krzykiem powierzył duszę Ojcu.

\section{Conformatio}

Tak, bracia, jeśli będziecie wieść trudne życie obserwancji z zamiarem podobania się Bogu, będziecie po prawicy Chrystusa z dobrym łotrem, którego cierpienia nie były daremne. Jeśli zaś w obserwancji szukacie ludzkiej chwały, będziecie ze złym łotrem po lewej, cierpiąc męki bezowocnie. Dzielicie między siebie szaty Chrystusa, kiedy naśladujecie postępowanie świętych, które jest symbolizowane przez szaty. Tak jak Piłat nie chciał zmienić tytułu Męki, tak wy nie powinniście usuwać $\mathrm{z}$ waszego serca pamięci o Męce Chrystusa. I tak jak Chrystus przyjął ocet, tak wszystko, co wcześniej było w was słodkie, stanie się gorzkie i kwaśne, abyście tak z najsmutniejszą Matką zasłużyli na odrobinę współcierpienia lub największego współczucia krzyża. Jak bowiem wspomniał Jan, sama stała obok krzyża Jezusa. O słowo tak wielkiego współczucia! Rozważcie więc, bracia: skoro coś godnego miłości, najbardziej przez was kochanego, zostało przekazane haniebnej śmierci, to jak bardzo nad tym bolejecie i współczujecie? Tak myślcie o matce Jezusa: jakimiż cierpieniami był nękana, stojąc pod krzyżem, kiedy najukochańszego, którego ponad wszystkich śmiertelnych kochała, widziała potępionego najohydniejszą śmiercią? Wiele cierpiała, ponieważ bardzo kochała. I przyczynę bólu pokazała, gdyż kiedy podnosiła swoje zapłakane oczy, widziała, że jej ukochany wisi, a ona w niczym nie może Go pocieszyć. A kiedy rozejrzała się dokoła, zobaczyła ogromny ból, który okrutnie dręczył jej syna. Wcześniej w sercu zapowiedziała największą Mękę, po- 
secum crucifixum tenebat. Et quando uocem filii commendantem eam discipulo audiuit, cor maternum de dolore uehementissimo estuare cepit et gladius meroris pertransiuit animam eius. Vt ergo fratres karissimi cepta de passione hodie concludamus, hortor uos in Domino, ut passionem Christi, que debet esse tota spes et solacium uestrum, in cordibus uestris recondatur, ut tandem gloriosum atque sublimem ad dexteram patris sedentem perhenniter uidere mereamini, quod uobis concedere dignetur idem crucifixus Dei filius benedictus, qui cum Patre et Spiritu Sancto est unus Deus regnans per omnia secula seculorum. Amen. nieważ ukrzyżowany zabrał jej serce, razem ze sobą ukrzyżowanego nosiła. Kiedy usłyszała głos syna powierzającego ją uczniowi, serce matki z gwałtownego bólu zaczęło płonąć i miecz żałości przeszył jej duszę. Abyśmy więc, bracia najdrożsi, powzięli dziś zamiary odnośnie do Męki, zachęcam was w Panu, aby Męka Chrystusa, która powinna być całą waszą nadzieją i pocieszeniem, w waszych sercach była przechowywana, abyście ostatecznie stali się godni oglądać sławnego i wspaniałego, wiecznie siedzącego po prawicy Ojca, na co wam dozwolić niech raczy sam ukrzyżowany Syn Boga błogosławionego, który z Ojcem i Duchem Świętym jest jedynym Bogiem królującym przez wszystkie wieki wieków. Amen.

\section{Ioel II 12-13.}

Peccatum... commutabile: cf. Augustinum Hipponensem, De libero arbitrio, lib. II, cap. 19, n. 53 (PL 32, 1269; CCSL 29, p. 272, lin. 72-73).

Philippenses III 8.

I Timoteum II 4.

Sapientiae XI 24-25.

Ieremiae XXXI 3.

Ioel II 12-13.

Iohannis XV 5.

Cf. Henricum Susonem, Horologium Sapientiae, lib. I, cap. 14 (Ed. J. Strange. Coloniae 1861, p. 126).

Meditatio... diminuit: cf. ibidem (p. 127).

Matthaei XVI 24.

I Petri II 21.

Cf. Henricum Susonem, Horologium Sapientiae, lib. I, cap. 15 (Ed. J. Strange. Coloniae 1861, p. 132).

Cf. ibidem, cap. 3 (p. 31).

Hanc... conformare: cf. ibidem (p. 32).

Nam... Christi: cf. ibidem, prol. (p. 12).

angelica] angelice $\mathrm{W}^{2}$

Audi... eius: Ecclesiastici VI 24-26.

In nouissimis... oblectationem: Ecclesiastici VI 29.

Modicum... delectationem: cf. Ecclesiastici LI 35; Henricum Susonem, Horologium Sapientiae, lib. I, cap. 1 (Ed. J. Strange. Coloniae 1861, p. 18). 
Morsellus primus passionis Iesu Christi $>\mathrm{W}^{2}$

uite ad eandem $>\mathrm{W}^{2}$

Cf. ibidem (p. 29).

Christus] Spiritus $\mathrm{W}^{2}$

Genesis II 17.

Captivetur... Dei: cf. Iohannem Damascenum, De fide orthodoxa, lib. IV, cap. 22 (PG 94, 292).

Cf. Albertum Magnum, Enarrationes in primam partem Evang. Lucae (I-IX). IX 46 (Ed. A. Borget. T. 22. Parisiis 1894, p. 678).

Peccatum... mortale: cf. Thomam de Aquino, Sth II-II. q. 186, a. 9, arg. 3 (Editio Leonina, T. 10. Romae 1899, p. 500).

Cf. ibidem, q. 72, a. 1, co (T. 9: 1897, p. 127).

Doctor] dicit praem. $\mathrm{W}^{1 \text { sec. } \mathrm{m} .} \mathrm{W}^{2}$

declarat $>\mathrm{W}^{2}$

Cf. ibidem, a. 2, co (p. 129).

Cf. ibidem, q. 68, a. 3, ad 1 (p. 106).

Św. Tomasz z Akwinu, Suma teologiczna. Przeł. F. Bednarski. T. 18. London 1970, s. 158.

unus... cedis: Iohannis XVIII 22-23.

prebet] prebere $\mathrm{W}^{1 \text { sec. } \mathrm{m} .} \mathrm{W}^{2}$

Marci XIV 62.

fuerint] fuerunt $\mathrm{W}^{2}$

Cf. Henricum Susonem, Horologium Sapientiae, lib. II, cap. 6 (Ed. J. Strange. Coloniae 1861, p. 214).

principes] princeps $\mathrm{W}^{2}$

Iohannis II 19.

Cf. Isidorum Hispalensem, Sententiae, lib. III, cap. 55, n. 2 (PL 83, 727A; CCSL 111, p. 310, lin. $5-8)$.

Marci XIV 62.

Iudae I 9.

Quid... mortis: Matthaei XXVI 66.

Tales... lapidari: cf. Leviticus XXIV 16.

Cf. Henricum Susonem, Horologium Sapientiae, lib. II, cap. 6 (Ed. J. Strange. Coloniae 1861, p. 213).

Cf. Bedam Venerabilem, In epistulas septem catholicas, lib. IV, cap. 4 (PL 93, 106A; CCSL 121, p. 316, lin. 223).

se $>\mathrm{W}^{2}$

Cf. Hieronymum, Epistula XX, n. 17 (PL 22, 404; CCSL 54, p. 165, lin. 9). expuisset] conspuisset $\mathrm{W}^{2}$

Alio... afficiunt: cf. Gregorium Magnum, Moralia in Iob, lib. XX, n. 19 (PL 75, 164; CCSL 143A, p. 1036, lin. 6-8).

Iob XXX 10.

Conspui... lauaret: cf. Thomam de Hibernia, Manipulus florum. Placenza 1483, f. 120r.

Nam... irrigatur: non inuenimus.

uelari] uelare $\mathrm{W}^{2}$

Cf. Thomam de Hibernia, Manipulus florum. Placenza 1483, f. 120r.

Iohannis III 20. 


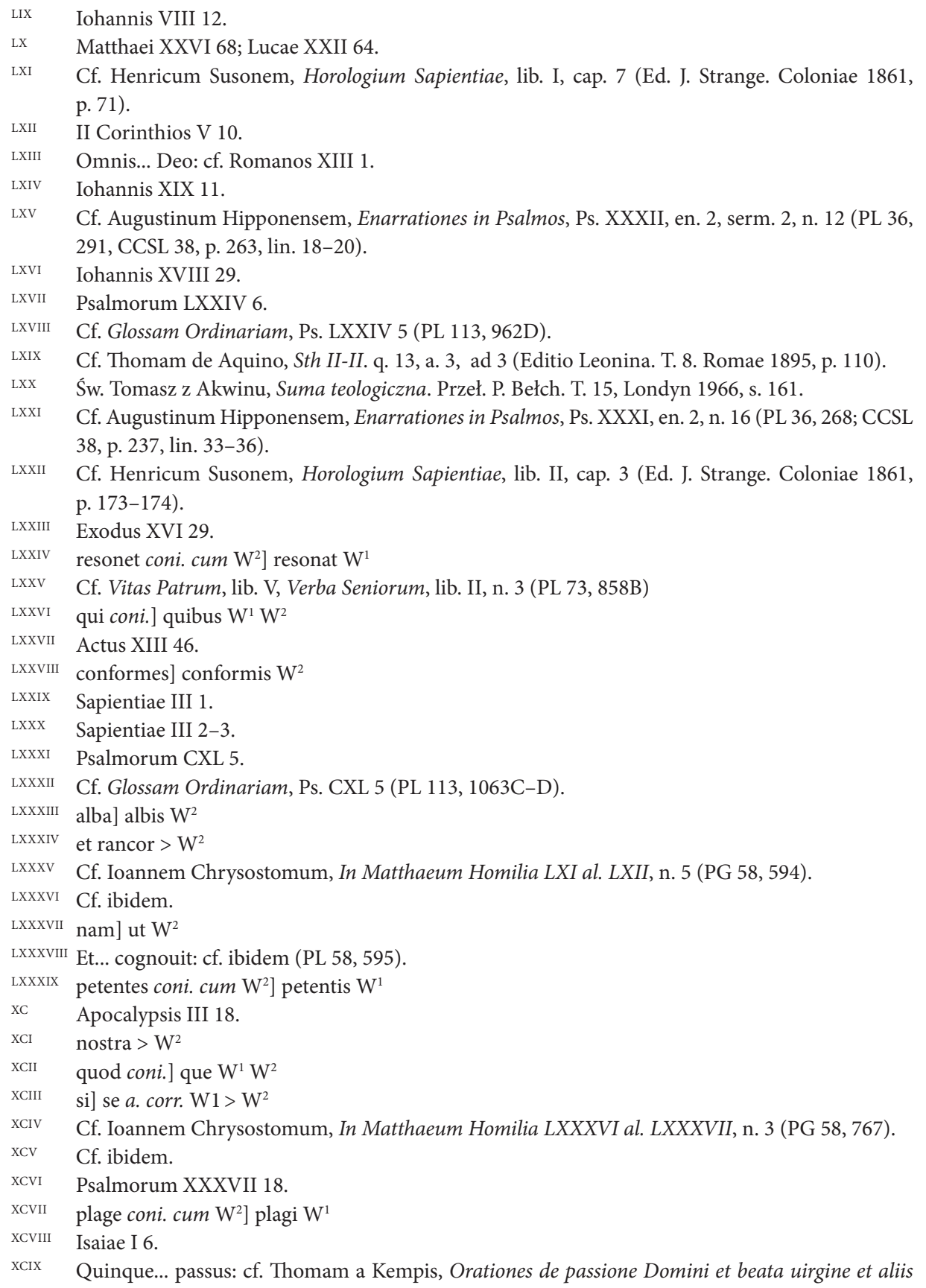


sanctis, vol. 3, oratio 4 (Thomae Hemerken a Kempis, Opera omnia. Voluminibus septem edidit additoque volumine de vita et scriptis eius disputavit Michael Iosephus Pohl. T. 3: Meditatio de incarnatione Christi. Sermones de vita et passione Domini. Alphabetum monachi. Van goeden woerden to horen ende die to spreken. Orationes de passione Domini et Beata Virginie et aliis sanctis. Friburgi Brisigavorum 1904, p. 347, lin. 10). uulneribus $>\mathrm{W}^{2}$ Non... amicorum: cf. Aristotelem, Ethica Nicomachaea, lib. VIII, cap. 5 (Ed. I. Bywater. Oxford 1894, 1157b19). Psalmorum XV 8.

contemplatione coni. cum $\mathrm{W}^{2}$ ] contemplationi $\mathrm{W}^{1}$

Anxiantur... carere: non inuenimus.

Psalmorum XV 8.

Matthaei XXVII 29; Marci XV 18; Iohannis XIX 3.

bona + opera $\mathrm{W}^{2}$

Cf. Matthaei X 22.

omnibus religiosis coni.] omni religioso $\mathrm{W}^{1} \mathrm{~W}^{2}$

Cf. Matthaei XII 36.

Matthaei XX 6.

Cf. Psalmorum XXXIII 9; Psalmorum XLVI 11.

Cf. Augustinum Hipponensem, Regula tertia uel Praeceptum (PL 32, 1380).

Augustyn, Pisma monastyczne. Przeł. P. Nehring. Kraków 2002, s. 159.

debemus] debetis $\mathrm{W}^{2}$

Marci XV 13.14; Iohannis XIX 6.15.

Marci XV 13-14.

Psalmorum LVI 5.

Cf. Augustinum Hipponensem, Enarrationes in Psalmos, Ps. LVI, n. 12 (PL 36, 669; CCSL 39, p. 702, lin. 29-31).

Augustyn, Objaśnienia psalmów. Ps. 36-37. Przeł. J. Sulkowski. Warszawa 1986, s. 372.

Iohannis XIX 12.

I Corinthios XI 32.

Cf. Symbolum fidei catholicae s. Athanasio adscriptum (D. Waterland, A Critical history of the Athanasian Creed, representing the opinions of antients and moderns concerning it, with an account of the manuscripts, versions and comments and such other particulars as are of moment for the determining the age, and author and value of it and the time of its reception in the Christian Churches, by Daniel Waterland, [...]. Cambridge 1724, p. 180).

L. Rzewuski, O prawdziwości wiary podług św. Augustyna. Kraków 1853, s. 229.

I Corinthios XI 31.

Cf. Gesta Pilati, cap. 9, n. 5 (Evangelia Apocrypha. Ed. C. Tischendorf. Lipsiae 1876, p. 360). Apokryfy Nowego Testamentu. Przeł. i oprac. M. Starowieyski. T. 1. Kraków 2003, s. 433. saluat] saluet $\mathrm{W}^{2}$

I Corinthios IV 3.

Psalmorum LVII 2.

Cf. Ps.-Hieronymum, Expositio Euangelii Marci, cap. 15 (CCSL 82, p. 73, lin. 50-52).

Cf. Bernardum Clareuallensem, Apologia ad Guillelmum abbatem, n. 2 (PL 182, 899D; Bernardi opera. Ed. J. Leclerq, H. M. Rochais. Vol. 3: 1963, p. 82, lin. 15). 


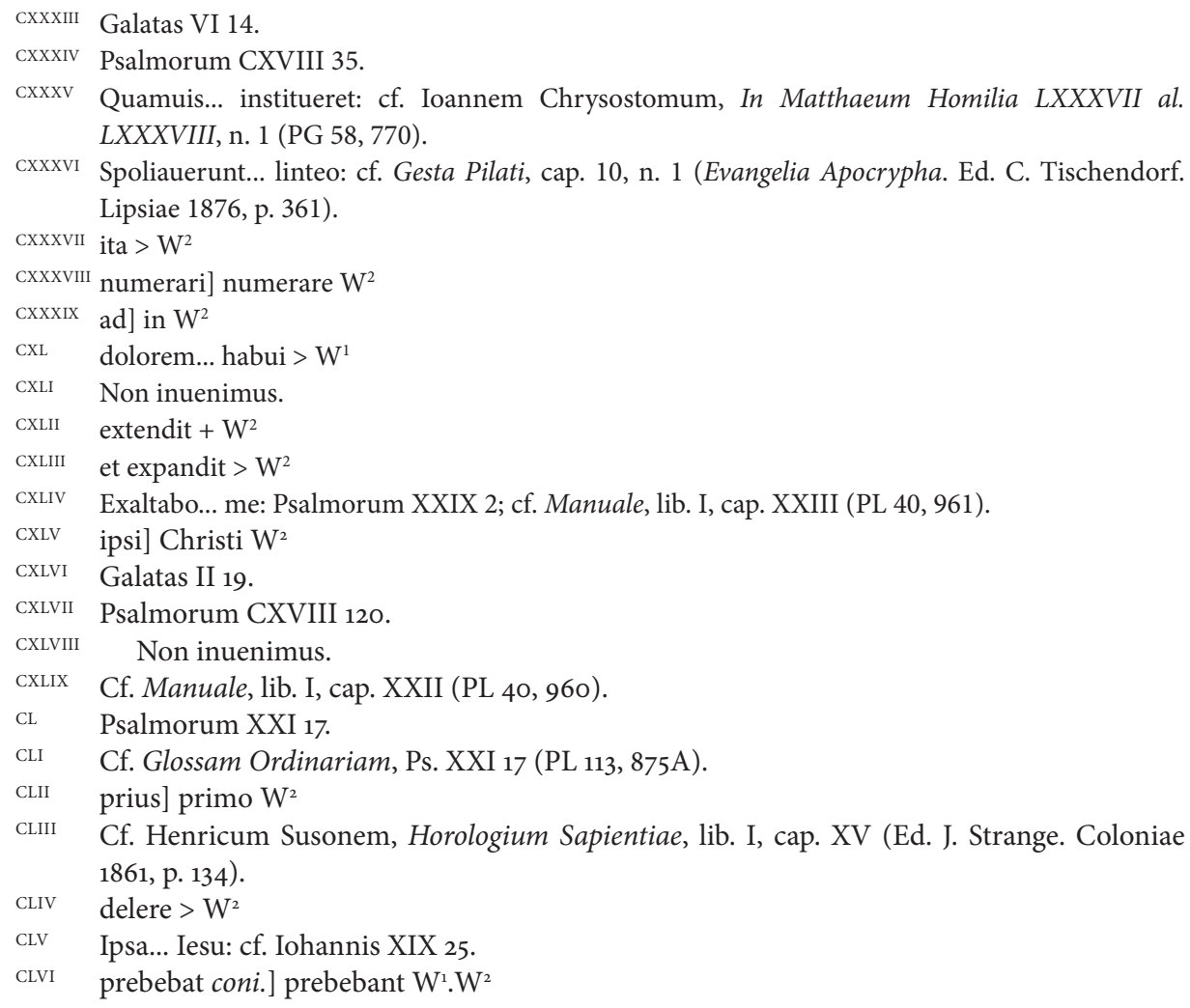




\section{Summary}

Towards the reform of medieval mendicant orders.

Exhortatio ad meditationem et conformationem passionis Christi

by Maciej Hayn ( $\$ 1477)$

Exhortatio ad meditationem et conformationem passionis Christi written by a Dominican Matthias Hayn in 1470 describes how the friars should make an effort to improve their behaviour towards others and deepen their spiritual life during Lent.

The author, who received good education while attending Dominican Studia Generalia in Cologne, Vienna and Paris, was designated by the Master General of the Order of Preachers to effect an observant reform in the Dominican Convent in Wrocław. Presumably Hayn wrote 'Exhortatio' as a part of his reform activities. The first part of the text is introduction, where Hayn explained the aim of his work. At the beginning he quoted the words from the first reading for Ash Wednesday: "return to me with all your heart, with fasting, with weeping, and with mourning" (Joel 2:12) and then he recommended to the brothers that these three acts of penance are the best way of reconciliation with God. According to Hayn the best example to follow in this matter is Christ, therefore during Lent the friars should ponder the Passion and seek to imitate Christ in their everyday situations, especially in those concerning life in monastery. The second part of Exhoratio (the main one) is divided into forty three short chapters called "Morselli" and each of them consists of "Passio" and "Conformatio". The first is a passage from the Passion parphrased by Hayn, the latter presents a commentary on the preceding "Passio" including advice for the friars.

This article comprises a critical edition of Exhortatio ad meditationem et conformationem passionis Christi accompanied by a Polish translation. The edition is based on two exisiting copies of the text which are contained in two manuscripts from the Wrocław University Library collection. 